\title{
4
}

\section{Hydrogen emissions to the atmosphere from industry and transportation}

\author{
STEVEN W. BOND, ROBERT ALVAREZ, STEFAN REIMANN, \\ MARTIN WEILENMANN, AND BRIGITTE BUCHMANN
}

\subsection{Introduction}

Hydrogen has the potential to become a sustainable energy carrier of the future, particularly for transportation. Until recently, $\mathrm{H}_{2}$ emissions to the atmosphere from anthropogenic sources have been largely disregarded and viewed in large part as a product of incomplete fossil fuel combustion. As $\mathrm{H}_{2}$ production and the fraction of energy-based $\mathrm{H}_{2}$ applications increase, a potential accumulation of $\mathrm{H}_{2}$ in the atmosphere from direct emissions, losses and leakage, and changes in chemical processes in both the troposphere and the stratosphere could result. Vehicle exhaust gas is currently an important source of anthropogenic $\mathrm{H}_{2}$ to the atmosphere, and losses of $\mathrm{H}_{2}$ from production, distribution, storage, and other end-use systems could become increasingly significant contributors. With changing vehicle fleet composition and increasing $\mathrm{H}_{2}$ demand and production for industrial and direct energy-based end-uses, an assessment of well-to-wheel $\mathrm{H}_{2}$ emissions, including $\mathrm{H}_{2}$ emissions from current and emerging vehicle technologies, will help assess the magnitude of future technological anthropogenic $\mathrm{H}_{2}$ emissions to the atmosphere.

\subsubsection{Objectives and scope}

Apart from the challenging technical questions associated with the production, transport, and storage of $\mathrm{H}_{2}$, future anthropogenic $\mathrm{H}_{2}$ emissions are an area of increased interest due to their prominence in the global $\mathrm{H}_{2}$ budget (see Figure 4.1). Currently, large uncertainty is associated with the contribution of $\mathrm{H}_{2}$ from technological processes, primarily from fossil fuels (white arrow, Figure 4.1). A detailed 


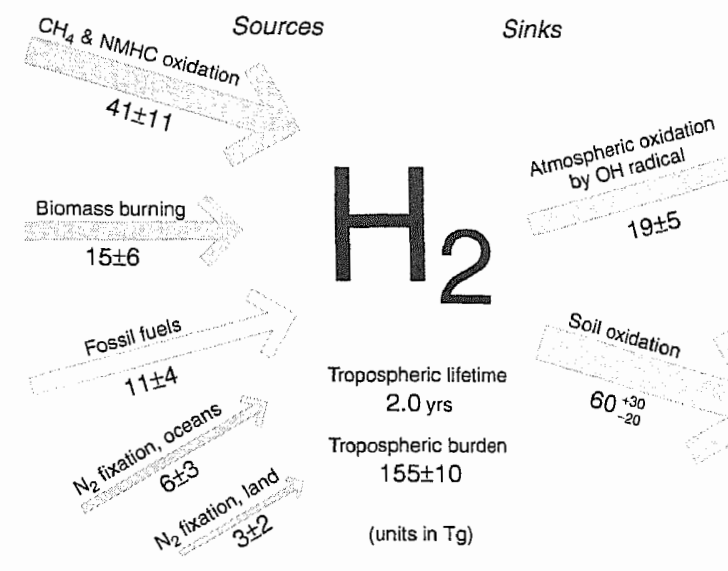

Figure 4.1 Global atmospheric $\mathrm{H}_{2}$ budget. Sources are detailed on the left, sinks on the right. Anthropogenic emissions from fossil fuel-based processes (white arrow) are the focus of this chapter. Adapted from Ehhalt and Rohrer (2009).

analysis of $\mathrm{H}_{2}$ emissions from the major anthropogenic processes that contribute to the present and future global $\mathrm{H}_{2}$ budget has been performed in this work and serves to better quantify the contribution from this sector.

In a collaboration between the Laboratory for Air Pollution/Environmental Technology and the Laboratory for Internal Combustion Engines at Empa, $\mathrm{H}_{2}$ emissions in the exhaust from various vehicle technologies were measured in order to help quantify the contribution of $\mathrm{H}_{2}$ to the atmosphere from direct emissions, and to map the processes involved in $\mathrm{H}_{2}$ evolution from current ICEV technologies. In addition, emission factors have been calculated to help formulate global $\mathrm{H}_{2}$ scenarios from road-based transportation considering variable vehicle technologies, emission standards, geography, and time periods. The main objective of this chapter is to apply this information to estimate future global technological anthropogenic $\mathrm{H}_{2}$ emissions considering changing vehicle fleet composition and global $\mathrm{H}_{2}$ production. This task is approached through scenarios on different time scales under the assumption that $\mathrm{H}_{2}$-based mobile applications and $\mathrm{H}_{2}$ production will increase throughout the twenty-first century.

Two separate scenarios (see Chapter 6) are assessed that relate emissions of $\mathrm{H}_{2}$ from road-based transportation with emissions derived from industrial and direct energy-based processes. In the baseline (business-as-usual) scenario, $\mathrm{CO}_{2}$ emissions are left to increase unabated without the intervention of any specific climate policies aimed at addressing global climate change. Under this scenario, $\mathrm{H}_{2}$ production for energy services increases only very modestly throughout the twenty-first century, and FCVs do not penetrate the market at all. Under the $450 \mathrm{ppm} \mathrm{CO}_{2}$ climate policy scenario, specific mechanisms are applied that are 
designed to stabilise the atmospheric $\mathrm{CO}_{2}$ mixing ratio at $450 \mathrm{ppm}$ by the end of the twenty-first century. Under this scenario, $\mathrm{H}_{2}$ production for direct energy services increases significantly over the period of study, notably with the penetration of FCVs in the second half of the century and an exponential increase in $\mathrm{H}_{2}$ production for primary energy consumption. Under both scenarios, the changing $\mathrm{H}_{2}$ emissions from transportation are combined with projected losses from $\mathrm{H}_{2}$ production, distribution, storage, and other end-uses in order to provide an overview of projected overall technological anthropogenic $\mathrm{H}_{2}$ emissions to the atmosphere throughout the twenty-first century. Scenarios have been formulated for 2010, 2020,2050 , and 2100 .

\subsection{State of research}

\subsubsection{Hydrogen in the atmosphere}

After methane $\left(\mathrm{CH}_{4}\right), \mathrm{H}_{2}$ is the second most abundant trace gas in the atmosphere. $\mathrm{H}_{2}$ can be considered an indirect GHG because it can lead to the production of tropospheric ozone $\left(\mathrm{O}_{3}\right)$, and it participates in a competing reaction with $\mathrm{CH}_{4}$ for the hydroxyl radical (OH) (Derwent et al., 2001; Prather, 2003), which is the primary atmospheric 'cleansing' agent. $\mathrm{OH}$ initiates the removal of both $\mathrm{H}_{2}$ and $\mathrm{CH}_{4}$ from the atmosphere. It is therefore plausible that increasing $\mathrm{H}_{2}$ mixing ratios in the atmosphere could increase the lifetime and thus the radiative forcing of $\mathrm{CH}_{4}$, since the $\mathrm{OH}$ radical may react increasingly with $\mathrm{H}_{2}$ rather than with $\mathrm{CH}_{4}$ (Schultz et al., 2003). Through its indirect radiative effects and relationship with other direct GHGs, climate implications have therefore been coupled with tropospheric $\mathrm{H}_{2}$ (Forster et al., 2007). Furthermore, it has been suggested that increasing $\mathrm{H}_{2}$ emissions at the surface could result in increasing $\mathrm{H}_{2}$ in the stratosphere ${ }^{1}$, which in turn could lead to an increase in stratospheric water vapour, with potentially dire consequences for the ozone layer (Tromp et al., 2003). This assertion is, however, debatable, as Ehhalt and Rohrer (2009) have pointed out that the weak vertical gradient of hydrogen in the upper troposphere ${ }^{2}$ and lower stratosphere means that virtually no export of $\mathrm{H}_{2}$ into the stratosphere will occur. Rohs et al. (2006) have also reported that the contribution of stratospheric $\mathrm{H}_{2}$ to the water vapour trend is minor. Any losses of $\mathrm{H}_{2}$ to the stratosphere would, however, likely occur as convective injections in the tropical regions. The focus here will be on ground-based emissions.

One of the earliest estimations of $\mathrm{H}_{2}$ in the troposphere comes from measurements made in 1923, where Paneth (1937) estimated the atmospheric $\mathrm{H}_{2}$ mixing

\footnotetext{
The stratosphere is the atmospheric layer from approximately 10 to $50 \mathrm{~km}$ above the earth's surface.

2 The troposphere is the atmospheric layer up to approximately $10 \mathrm{~km}$ above the earth's surface.
} 


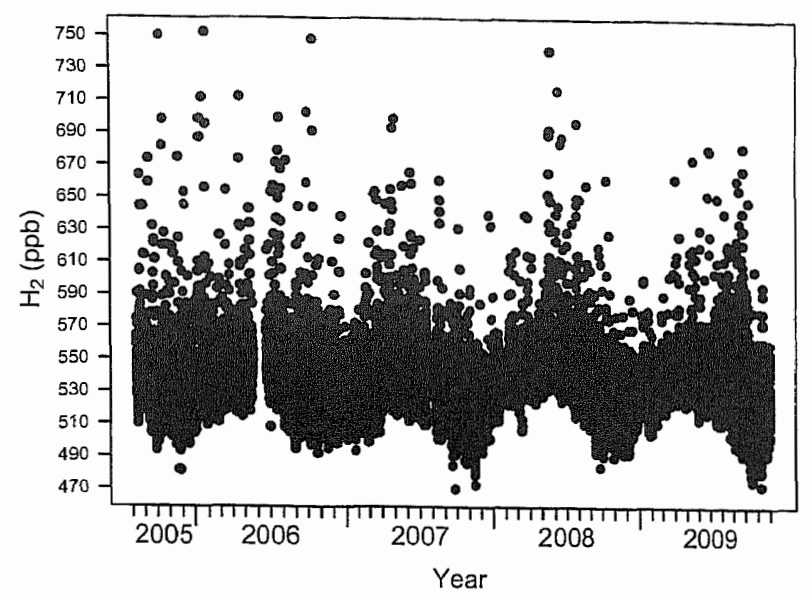

Figure 4.2 Atmospheric $\mathrm{H}_{2}$ measured at the high altitude site Jungfraujoch, Switzerland. The dataset covers the period August 2005-November 2009. The black band represents background levels, while pollution and depletion events are seen bordering either side of the background measurements. Adapted from Bond et al. (2011b).

ratio to be approximately 0.5 parts per million (ppm). This estimation is remarkably similar to today's much more accurate measurements of approximately 530 parts per billion (ppb; $\approx 0.53 \mathrm{ppm}$ ) globally (Novelli et al., 1999), and would suggest that the overall atmospheric mixing ratio of $\mathrm{H}_{2}$ has not changed significantly over the past century, despite the annually increasing number of motor vehicles on the global scale. The lack of a long-term trend in background tropospheric $\mathrm{H}_{2}$ in the last decades in Europe (Grant et al., 2010) supports this finding. In fact, measurements at remote tropospheric sites should function as effective tools to monitor the behaviour of $\mathrm{H}_{2}$ during the transition to more $\mathrm{H}_{2}$-intensive applications (e.g. through long-term trend monitoring). As an example, Figure 4.2 depicts atmospheric $\mathrm{H}_{2}$ mixing ratios at the remote high-Alpine site Jungfraujoch, Switzerland, (adapted from Bond et al., 2011b).

The sink strength in the global $\mathrm{H}_{2}$ budget is dominated by oxidative processes within the soil involving enzymes called hydrogenases. This term has been estimated at representing between $~ 75-90 \%$ of the global $\mathrm{H}_{2}$ sink (Conrad and Seiler, 1985; Hauglustaine and Ehhalt, 2002; Rahn et al., 2003; Sanderson et al., 2003; Rhee et al., 2006; Price et al., 2007). Given the first-order reaction kinetics of $\mathrm{H}_{2}$ oxidation by soil processes (Conrad and Seiler, 1981), it is plausible that an increase in atmospheric $\mathrm{H}_{2}$ mixing ratios would be offset by enhanced $\mathrm{H}_{2}$ uptake by soils. This assumption is backed by the striking similarity in the results of measurements of mean tropospheric $\mathrm{H}_{2}$ throughout the 
twentieth century, despite global increases in motor vehicles with inefficient emission control systems compared with today's standards. Nevertheless, an upper-end threshold boundary beyond which this assumption may not hold is equally plausible.

The global source strength of $\mathrm{H}_{2}$ from fossil fuels has been estimated at between 11-20 Tg/year (Novelli et al., 1999; Sanderson et al., 2003; Rhee et al., 2006; Xiao et al., 2007; Ehhalt and Rohrer, 2009), a significant contribution to the entire source term of atmospheric $\mathrm{H}_{2}$ (see Figure 4.1). The contribution from traffic exhaust represents the major source of $\mathrm{H}_{2}$ from fossil fuel-based processes (Schmidt, 1974; Novelli et al., 1999; Barnes et al., 2003; Ehhalt and Rohrer, 2009). Novelli et al. (1999) reported a range of $\mathrm{H}_{2}$ emissions strictly from transportation at $5-20 \mathrm{Tg}$ / year, while Vollmer et al. (2007) and Ehhalt and Rohrer (2009) reported estimates at the lower end of that range at $5.4 \pm 3.2$ and $9 \pm 3 \mathrm{Tg}$ /year, respectively. Other processes, such as the reformation of hydrocarbons, currently represent a comparatively minor fossil fuel-based source of $\mathrm{H}_{2}$ to the atmosphere (Ehhalt and Rohrer, 2009).

\subsubsection{Hydrogen emissions in internal combustion engine exhaust: the role of airlfuel ratios and lambda}

$\mathrm{H}_{2}$ emissions in ICEV exhaust result from incomplete fuel combustion in the absence of oxygen $\left(\mathrm{O}_{2}\right)$. Carbon monoxide $(\mathrm{CO})$ emissions evolve under these same conditions, which creates a strong positive correlation between $\mathrm{H}_{2}$ and $\mathrm{CO}$ in direct vehicle exhaust measurements. The air/fuel ratio - the ratio of the mass of air supplied to the engine to the mass of fuel supplied to the engine over the same time period - plays an important role. Lambda $(\lambda)$ is a measure of the extent of the excursion of the air/fuel ratio relative to stoichiometry ${ }^{3}$. A $\lambda$ value of 1 is at stoichiometry, whereas a value above 1 indicates an excess of air (lean-burn (oxidising) condition), and a value below 1 indicates the opposite (rich-burn (reducing) condition). Modern engines control $\lambda$ at 1 using lambda sensors mounted both upand downstream of the catalyst. With current technologies, gasoline engines for passenger vehicles are typically operated under stoichiometric conditions whenever possible, during which the air/fuel ratio is optimal to ensure complete fuel combustion in both the engine and catalyst. Exceptions are situations requiring extended periods of high power, during which rich stoichiometry is selected to cool the engine and the catalyst, short periods where the engine control unit (ECU) cannot perfectly maintain lambda at 1 , or when rich conditions are chosen to clear

${ }^{3}$ The stoichiometric air/fuel ratio for a particular fuel type is the air/fuel ratio that ensures complete combustion of all carbon and hydrogen without any remaining oxygen. 
out $\mathrm{O}_{2}$ from the catalyst after fuel cut-off phases. Diesel vehicles always operate under 'fuel-lean' oxidising conditions, where air/fuel ratios are consistently above stoichiometric conditions, leading to much lower mixing ratios (and often untraceable levels) of $\mathrm{H}_{2}$ in exchange for higher levels of nitrogen oxides $\left(\mathrm{NO}_{\mathrm{x}}\right.$, nitric oxide $(\mathrm{NO})+$ nitrogen dioxide $\left(\mathrm{NO}_{2}\right)$ ).

\subsubsection{Three-way catalytic converters}

Increasingly stringent legislation on emissions of $\mathrm{CO}, \mathrm{NO}_{\mathrm{x}}$, and hydrocarbons in response to air pollution and the rising awareness of adverse effects on human health, anthropogenic infrastructure, and biota has led to the advent of three-way catalytic converters (TWCs), which simultaneously promote the oxidation of $\mathrm{CO}$ and hydrocarbons, along with the reduction of $\mathrm{NO}_{\mathrm{x}}$. Although TWCs are not always mandated by legislation, it has become impossible to reduce emissions below legislated limits without them.

Overall, TWCs remove $\mathrm{H}_{2}$ from raw vehicle exhaust. $\mathrm{H}_{2}$ emissions from vehicles without TWCs are much higher than from those equipped with exhaust aftertreatment systems ${ }^{4}$. However, today's TWCs are also designed to promote watergas shift and steam reforming reactions (Auckenthaler, 2005), which ultimately results in the production of some $\mathrm{H}_{2}$ through the destruction of hydrocarbons, $\mathrm{CO}$, and water $\left(\mathrm{H}_{2} \mathrm{O}\right)$ under fuel-rich conditions. In steam reforming reactions, hydrocarbons are oxidised by $\mathrm{H}_{2} \mathrm{O}$ to produce $\mathrm{CO}$ and $\mathrm{H}_{2}$. Steam reforming reactions are endothermic (i.e. they require the input of heat and proceed at high temperatures). The general equation for the steam reforming of hydrocarbons is:

$$
\mathrm{C}_{\mathrm{n}} \mathrm{H}_{2 \mathrm{n}+2}+\mathrm{nH}_{2} \mathrm{O} \rightarrow \mathrm{nCO}+(2 \mathrm{n}+1) \mathrm{H}_{2}
$$

(Enthalpy change $(\Delta \mathrm{H})$ positive)

The water-gas shift reaction is exothermic (i.e. gives off heat and proceeds at lower temperatures), consuming $\mathrm{CO}$ and producing $\mathrm{H}_{2}$ in the process:

$$
\mathrm{CO}+\mathrm{H}_{2} \mathrm{O} \rightarrow \mathrm{CO}_{2}+\mathrm{H}_{2}
$$

$(\Delta \mathrm{H}$ negative)

Ageing of a catalytic converter can have a significant effect on the level of $\mathrm{H}_{2}$ emissions over the lifetime of a TWC. For example, Auckenthaler (2005) observed much higher water-gas shift and steam reforming activity with a fresh TWC than with an aged device.

4 It is important to note that not only do TWCs remove $\mathrm{H}_{2}$ and other substances from vehicle exhaust, but current vehicle technologies also often have more sophisticated and precise onboard computer systems that consistently regulate the air/fuel ratio at the stoichiometric point. The result is much lower emissions compared with older vehicle technologies (or vehicles without a TWC). 


\subsubsection{Hydrogen emissions from test bench, chassis dynamometer, and real-world studies involving internal combustion engine vehicles}

The processes of $\mathrm{H}_{2}$ production and emission have been assessed in a limited number of cases through studies involving vehicles simulating real-world driving conditions. A wide range of $\mathrm{H}_{2}$ emission factors for a series of gasoline-powered Euro-3 automobiles tested on a chassis dynamometer were observed (Heeb et al., 2006). The range was largely attributed to the various driving conditions characteristic of the different cycles and sub-cycles. $\mathrm{H}_{2}$ emission factors were found to be highly dependent on speed and acceleration patterns. The mean $\mathrm{H}_{2}$ emission factor $\left(\mathrm{E}_{\mathrm{H} 2}\right)$ across a range of urban, rural, and highway sub-cycles was calculated to be $59.4 \mathrm{mg} / \mathrm{km}$. A separate chassis dynamometer study involving gasoline-powered Euro-4 automobiles and the same driving conditions resulted in a mean $\mathrm{E}_{\mathrm{H} 2}$ of $26.5 \mathrm{mg} / \mathrm{km}$ (Bond et al., 2010), illustrating the systematic development of TWCs and exhaust after-treatment systems as emissions limits tighten. Newer vehicles are also equipped with better $\lambda$ control systems, which provide more consistent regulation around the stoichiometric air/fuel ratio, and thus fewer fuel-rich excursions and lower resultant emissions.

Tunnel studies eliminate the influence from other local source and sink factors, and can thus provide robust information about $\mathrm{H}_{2}$ emissions from real-world vehicle fleets. In a tunnel study in Switzerland, an $\mathrm{E}_{\mathrm{H} 2}$ of $67 \mathrm{mg} / \mathrm{km}$ for a gasolinebased traffic fleet comprising a wide range of emission standard technologies was reported (Vollmer et al., 2007). A much smaller $\mathrm{E}_{\mathrm{H} 2}$ was found for heavy-duty vehicles than for LDVs, a trait pinned to the much lower $\mathrm{H}_{2}$ emissions from diesel compared with gasoline technologies.

In a test bench study involving emission measurements from an LDV engine (Vollmer et al., 2010), pre-TWC measurements displayed predictable concentrations of both $\mathrm{H}_{2}$ and $\mathrm{CO}$ in the exhaust gas under variable air/fuel ratios (see Figure 4.3). Because of this correlation, and the much more well-constrained $\mathrm{CO}$ contribution from vehicle exhaust, the molar ratio of $\mathrm{H}_{2} / \mathrm{CO}$ has been considered a central topic in previous studies involving older vehicle technologies for establishing the $\mathrm{H}_{2}$ contribution from fossil fuel combustion processes, primarily transportation (Schmidt, 1974; Novelli et al., 1999; Barnes et al., 2003; Steinbacher et al., 2007; Vollmer et al., 2007; Aalto et al., 2009; Hammer et al., 2009; Yver et al., 2009).

\subsubsection{Direct emissions of hydrogen to the atmosphere from production, distribution, storage, and non-transport end-use systems}

Direct emissions of $\mathrm{H}_{2}$ to the atmosphere from non-transport end-use systems also contribute to the overall source from anthropogenic processes. Currently, the 


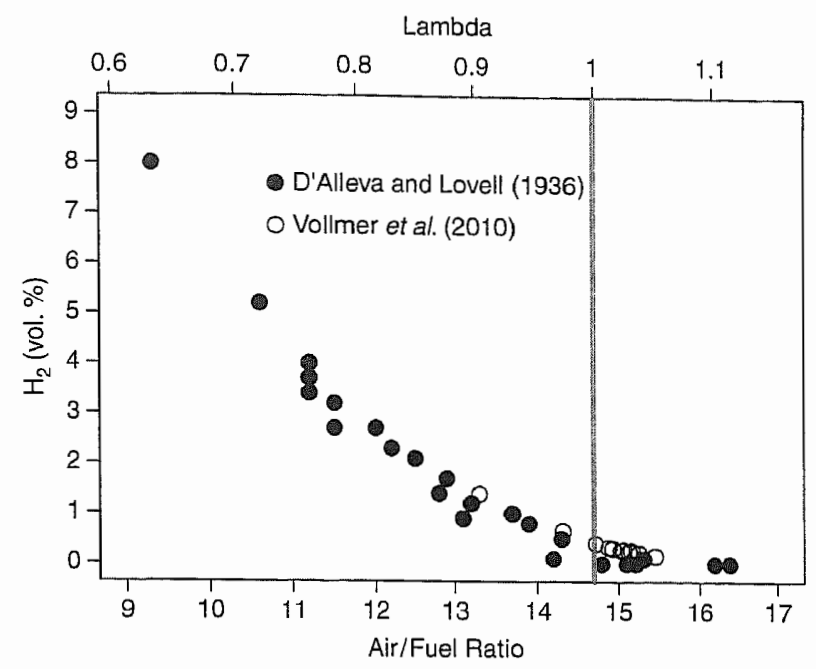

Figure $4.3 \mathrm{H}_{2}$ mixing ratios in raw gasoline exhaust gas. Measurements cover an air/fuel ratio ranging from approximately 9-17. The approximate corresponding $\lambda$ values are shown on the upper $x$-axis. The filled circles are from D'Alleva and Lovell (1936), the open circles from Vollmer et al. (2010). The dark grey vertical line represents stoichiometric $(\lambda=1)$ conditions.

majority of these losses are likely derived from fossil fuels during the production of $\mathrm{H}_{2}$ for industrial processes (e.g. fossil fuel reforming). Captive uses of $\mathrm{H}_{2}$ are those where hydrogen is produced and consumed directly on-site. These are primarily the petroleum refining, ammonia $\left(\mathrm{NH}_{3}\right)$ fertiliser production, and methanol $\left(\mathrm{CH}_{3} \mathrm{OH}\right)$ production industries, which, combined, account for $\sim 92 \%$ of global $\mathrm{H}_{2}$ production ( $\mathrm{CEH}, 2007$ ). Of this $\mathrm{H}_{2}$ production, approximately $95 \%$ is produced from fossil fuels (Ogden, 2004). Future losses and leakage of $\mathrm{H}_{2}$ will not only depend on methods of production, but also on strategies for the distribution, storage, and end-uses of $\mathrm{H}_{2}$. It is widely accepted that emissions from cryogenic liquid $\mathrm{H}_{2}$ dominate those of $\mathrm{H}_{2}$ stored in the compressed gaseous form. An estimated range of $\mathrm{H}_{2}$ loss rates due to 'boil off' or evaporation from liquid $\mathrm{H}_{2}$ would be on the order of $0.1-10 \%$ over the entire production, distribution, and end-use chain (Zittel and Altmann, 1996; Schlapbach and Züttel, 2001; Burns et al., 2002; Kammen and Lipman, 2003; Schultz et al., 2003; de Wit and Faaig, 2007; Sherif et al., 2007; R.J. Natkin, personal communication, 2008). This range is based on leakage from mature delivery and end-use systems, including pipelines, storage systems, compressors, pumps, and vehicles. Losses associated with high-pressure gaseous $\mathrm{H}_{2}$ are lower than those associated with liquid $\mathrm{H}_{2}$. The estimated loss of compressed gaseous $\mathrm{H}_{2}$ from mature systems is marginal up to approximately $4 \%$ over the entire production, distribution, and end-use chain (Zittel and Altmann, 1996; Kammen and Lipman, 2003; Lovins, 2003; Schultz et al., 2003; R.J. Natkin, personal communication, 2008; F. Balzer, personal communication, 2008). 
Although a large-scale $\mathrm{H}_{2}$-intensive economy would involve significantly greater $\mathrm{H}_{2}$ production volumes for direct energy services, losses of $\mathrm{H}_{2}$ to the atmosphere are not unanimously expected to increase considerably, despite the diffusive nature of $\mathrm{H}_{2}$. Instead, it could be anticipated that losses actually decline as the maturity of the hydrogen chain develops (Bond et al., 2011a). Loss rates estimated by industry tend to be lower, which may indeed be based on more realistic and reliable information from those involved in the industry, where safety, ecological, and monetary concerns highlight the agenda. The higher-end loss rates are often based on results from model studies (Tromp et al., 2003). The high-end loss rate scenarios, on the one hand, provide important reminders about the proper diligence required during the transition toward an increasingly $\mathrm{H}_{2}$-intensive economy, while on the other hand, they are potentially overestimated in today's technology-driven society.

\subsection{Methodology for the assessment of hydrogen emissions}

To characterise $\mathrm{H}_{2}$ emissions from current technology vehicles, the exhaust gas from a number of vehicles was measured. Vehicle types included light-duty gasoline and diesel vehicles, two-wheelers (motorcycles and scooters), and natural gas automobiles. All four-wheeled vehicles were subject to the constraints of the Euro-4 emission standards, while the two-wheelers complied with the twowheeler, Euro-3 emission standards. All vehicle measurements were conducted on a chassis dynamometer, which allows for the simulation of dynamic driving conditions under controlled laboratory settings. For details of the experimental setup, see Vasic and Weilenmann (2006) and Alvarez et al. (2009). A total of six cycles were tested for the four-wheeled vehicles and four cycles were tested for the twowheeled vehicles in order to adequately capture the real-world characteristics of urban, rural, and highway driving conditions. Each cycle comprises three separate sub-cycles. For details of the individual driving cycles, see Bond et al. (2010).

All direct online $\mathrm{H}_{2}$ measurements were conducted with an $\mathrm{H}$-Sense process mass spectrometer (V\&F Analyse- und Messtechnik $\mathrm{GmbH}$ ), which operates according to the electron ionisation mass spectrometry measurement principle. See Heeb et al. (2006) and Bond et al. (2010) for further details of the instrument.

Emission factors are widely used to quantify vehicle emissions and are often expressed as the mass of a pollutant per unit time or vehicle distance travelled. The calculation of vehicle emission factors is not only important for monitoring regulated and other pollutants of interest in vehicle exhaust, but also serves as a tool for quantifying and upscaling emissions to constrain specific source terms of atmospheric budgets. Hydrogen emission factors $\left(\mathrm{E}_{\mathrm{H} 2}\right)$ were calculated through the combination of molar $\mathrm{H}_{2}$ mixing ratios in the exhaust gas and the exhaust mass flow. A detailed description of the calculation of $\mathrm{E}_{\mathrm{H} 2}$ from vehicles measured directly 
on the chassis dynamometer can be found in Bond et al. (2010). For vehicle technologies not directly tested on the chassis dynamometer, emission factors were calculated from other independent measurements and assumptions made about the individual technologies. For details of the derivation of $\mathrm{E}_{\mathrm{H} 2}$ for these vehicle technologies, see Bond et al. (2011a).

The emissions factors $\left(\mathrm{E}_{\mathrm{H} 2}\right)$ for the various vehicle types were applied to globally upscale emissions from transportation (Section 4.4.2, Table 4.1). As vehicle technologies, global kilometres travelled, technologies designed to address vehicle exhaust emissions, and emissions/emission standards for different world regions are different and change with time, a number of assumptions were formulated to develop an accurate account of global $\mathrm{H}_{2}$ emissions over the subject time horizon. In formulating these assumptions, effort has been made throughout this chapter to coordinate and reconcile details with other chapters, particularly Chapter 6 for fleet progression and Chapter 3 for vehicle technology. The main assumptions are as follows:

1. The percentage share of each LDV technology for 2010, 2020, 2050, and 2100 are based on results of least-cost optimisation modelling, using the PSI's Global Multi-regional MARKAL (GMM) model. This is a bottom-up model of the global energy system, with detailed representation of energy and passenger transport technologies, energy resources, and demands. The model is applied to study scenarios of global energy and transport system development - in this case, a baseline (business-as-usual) scenario and a scenario consistent with achieving a stable atmospheric $\mathrm{CO}_{2}$ mixing ratio of $450 \mathrm{ppm}$. See Chapter 6 for details of the model and list of LDV technologies considered in this study.

2. Projections of global LDV kilometres separated by world region in 2010 and 2020 are based on model results from Fulton and Eads (2004). This second model (the Sustainable Mobility Project (SMP) transport model) captures the variability surrounding global emissions based on region, emissions/ emission standards, and vehicle technologies supplementary to LDVs. In addition to LDVs, two-wheelers, medium-sized trucks, large buses, and mini-buses are considered, to be as inclusive as possible with vehicle technologies responsible for significant $\mathrm{H}_{2}$ emissions. Heavy-duty trucks are all assumed to be diesel-based, from which $\mathrm{H}_{2}$ emissions are assumed to contribute only marginally on a global scale (Bond et al., 2011a). These additional criteria allowed us to complement the GMM and more comprehensively map the complex variability inherent to current and near-term emissions conditions.

3. Beyond 2020 (i.e. for 2050 and 2100 scenarios), projections of global LDV kilometres and emissions are exclusively according to the GMM. The separation by world region (as described in assumption 2) was not applied because 
$\overrightarrow{\&} \quad$ Table 4.1. $\mathrm{H}_{2}$ emission factors for all vehicle technologies and world regions considered in this study (Bond et al., 2011a). The letters for each time period represent the $E_{H 2}$ that was applied for each world region. 'all' signifies that all world regions were subject to that particular $E_{H 2}$. All $E_{H 2}$ are reported in $\mathrm{mg} / \mathrm{km}$. Letters for each time period refer to: (a) Organisation for Economic Co-Operation and Development (OECD) North America, (b) OECD Europe, (c) OECD Pacific (Japan, Korea, Australia, New Zealand), (d) Former Soviet Union, (e) Eastern Europe, (f) China, (g) other Asia, ( $h$ ) India, (i) Middle East, (j) Latin America, and (k) Africa.

\begin{tabular}{|c|c|c|c|c|c|}
\hline Vehicle Technology Class & $\mathrm{E}_{\mathrm{H} 2}$ & 2010 & 2020 & 2050 & 2100 \\
\hline \multicolumn{6}{|l|}{ Gasoline automobiles } \\
\hline 1. pre-Euro-1 & 1130 & $\mathrm{i}, \mathrm{k}$ & - & - & - \\
\hline 2. Euro-1 & 283 & $\mathrm{~d}, \mathrm{e}, \mathrm{f}, \mathrm{g}, \mathrm{h}, \mathrm{j}$ & - & - & - \\
\hline 3. Euro-2 & 108 & - & $\mathrm{i}, \mathrm{k}$ & - & - \\
\hline 4. Euro-3 & 59.4 & $a, b, c$ & $\mathrm{~d}, \mathrm{e}, \mathrm{f}, \mathrm{g}, \mathrm{h}, \mathrm{j}$ & - & - \\
\hline 5. Euro-4 & 26.5 & - & - & - & - \\
\hline 6. post Euro-4 & 26.5 & - & $\mathrm{a}, \mathrm{b}, \mathrm{c}$ & all & all \\
\hline \multicolumn{6}{|l|}{ Gasoline two-wheelers } \\
\hline 1. Based on $E_{\mathrm{CO}}$ of $20 \mathrm{~g} / \mathrm{km}$ & 793 & $\mathrm{~d}, \mathrm{e}, \mathrm{f}, \mathrm{g}, \mathrm{h}, \mathrm{i}, \mathrm{j}, \mathrm{k}$ & - & - & - \\
\hline 2. Based on $\mathrm{E}_{\mathrm{CO}}$ of $15 \mathrm{~g} / \mathrm{km}$ & 595 & $\mathrm{a}, \mathrm{b}, \mathrm{c}$ & - & - & - \\
\hline 3. Based on $\mathrm{E}_{\mathrm{CO}}$ of $7.5 \mathrm{~g} / \mathrm{km}$ & 297 & - & d,e,f,g,h,i,j,k & - & - \\
\hline 4. Based on $\mathrm{E}_{\mathrm{CO}}$ of $6.575 \mathrm{~g} / \mathrm{km}$ & 261 & - & $\mathrm{b}$ & - & - \\
\hline 5. Based on $\mathrm{E}_{\mathrm{CO}}$ of $6.467 \mathrm{~g} / \mathrm{km}$ & 256 & - & $\mathrm{a}$ & - & - \\
\hline 6. Based on $\mathrm{E}_{\mathrm{CO}}$ of $4.628 \mathrm{~g} / \mathrm{km}$ & 184 & - & $c$ & - & - \\
\hline 7. Euro-3 & 141 & - & - & - & - \\
\hline 8. Post-Euro-3 & 26.5 & - & - & all & all \\
\hline \multicolumn{6}{|l|}{ Diesel vehicles } \\
\hline $\begin{array}{l}\text { Assumed to be same as diesel Euro- } 4 \text { vehicles based } \\
\text { on oxidising operating principle of diesel engines }\end{array}$ & 0.1 & all & all & all & all \\
\hline \multicolumn{6}{|l|}{ Gasoline medium-sized trucks/mini-buses } \\
\hline 1. Based on $E_{\mathrm{CO}}$ of $35 \mathrm{~g} / \mathrm{km}$ & 1390 & $\mathrm{~d}, \mathrm{e}, \mathrm{f}, \mathrm{g}, \mathrm{h}, \mathrm{i}, \mathrm{j}, \mathrm{k}$ & - & - & - \\
\hline 2. Based on $E_{C O}$ of $15 \mathrm{~g} / \mathrm{km}$ & 595 & - & d,e,f,g,h,i,j,k & - & - \\
\hline
\end{tabular}


Table 4.1 (cont.)

\begin{tabular}{|c|c|c|c|c|c|}
\hline Vehicle Technology Class & $\mathrm{E}_{\mathrm{H} 2}$ & 2010 & 2020 & 2050 & 2100 \\
\hline $\begin{array}{l}\text { 3. Based on } E_{\mathrm{CO}} \text { of } 7.5 \mathrm{~g} / \mathrm{km} \\
\text { 4. Based on } \mathrm{E}_{\mathrm{CO}} \text { of } 5.625 \mathrm{~g} / \mathrm{km} \\
\text { 5. Post-Euro-4 }\end{array}$ & $\begin{array}{r}297 \\
223 \\
26.5\end{array}$ & $\begin{array}{l}a, b, c \\
- \\
-\end{array}$ & $\begin{array}{l}- \\
a, b, c \\
-\end{array}$ & $\begin{array}{l}- \\
- \\
\text { all }\end{array}$ & $\begin{array}{l}- \\
- \\
\text { all }\end{array}$ \\
\hline $\begin{array}{l}\text { Gasoline large buses } \\
\text { 1. Estimated, based on } \mathrm{E}_{\mathrm{CO}} \text { of } 46.7 \mathrm{~g} / \mathrm{km} \\
\text { 2. Estimated, based on } \mathrm{E}_{\mathrm{CO}} \text { of } 20 \mathrm{~g} / \mathrm{km} \\
\text { 3. Estimated, based on } \mathrm{E}_{\mathrm{CO}} \text { of } 10 \mathrm{~g} / \mathrm{km} \\
\text { 4. estimated, based on } \mathrm{E}_{\mathrm{CO}} \text { of } 7.5 \mathrm{~g} / \mathrm{km} \\
\text { 5. post-Euro-4 }\end{array}$ & $\begin{array}{c}1850 \\
793 \\
397 \\
297 \\
26.5\end{array}$ & $\begin{array}{l}\text { d,e,f,g,h,i,j,k } \\
- \\
\mathrm{a}, \mathrm{b}, \mathrm{c} \\
- \\
-\end{array}$ & $\begin{array}{l}\text { d,e,f,g,h,i,j,k } \\
\text { a,b,c } \\
-\end{array}$ & $\begin{array}{l}- \\
- \\
- \\
- \\
\text { all }\end{array}$ & $\begin{array}{l}- \\
- \\
- \\
- \\
\text { all }\end{array}$ \\
\hline Natural gas vehicles & 73.5 & $a, b, c$ & $a, b, c$ & all & all \\
\hline Biofuels vehicles & 13.3 & $a, b, c$ & $a, b, c$ & all & all \\
\hline Gasoline HEVs & 23.1 & $a, b, c$ & $a, b, c$ & all & all \\
\hline Natural gas hybrid vehicles & 58.8 & $a, b, c$ & $a, b, c$ & all & all \\
\hline Biofuels hybrid vehicles & 10.6 & $\mathrm{a}, \mathrm{b}, \mathrm{c}$ & $\mathrm{a}, \mathrm{b}, \mathrm{c}$ & all & all \\
\hline Plug-in hybrid vehicles & 14.8 & $\mathrm{a}, \mathrm{b}, \mathrm{c}$ & $a, b, c$ & all & all \\
\hline $\mathrm{H}_{2}$ hybrid vehicles & 33.1 & - & $a, b, c$ & all & all \\
\hline $\mathrm{H}_{2}$ fuel cell vehicles & vary & - & - & all & all \\
\hline
\end{tabular}


all vehicles of similar technologies were assumed to have same $E_{\mathrm{H}_{2}}$ in 2050 and 2100, irrespective of region.

4. Projections of global kilometres for medium-sized trucks, large buses, and mini-buses for specific regions and time periods were derived from Fulton and Eads (2004), and based on kilometres driven by region for 2010 and 2020, total global kilometres in 2050 and the forecast according to regression for global kilometre projections to 2100 .

5. Projections of global two-wheeler kilometres for specific regions and time periods were derived from Fulton and Eads (2004), and based on kilometres driven by region in 2000 , projected model results based on two-wheeler ownership by region to 2050 , and the forecast according to the regression for kilometre projections to 2100 .

6. The percentage share of fuel types for conventional vehicle types (gasoline and diesel) are based on projections by Fulton and Eads (2004). This percentage share of gasoline- and diesel-based transportation applies to the oil products and synfuels ICEVs category described in Chapter 6.

7. Medium-sized trucks, large buses, and mini-buses were all assumed to be fuelled by either gasoline or diesel over the course of the study period.

8. Technologies other than conventional gasoline (including two-wheelers) and diesel vehicles (i.e. natural gas, biofuels, and all hybrid vehicles) were assumed to be incorporated only into developed-country vehicle fleets for 2010 and 2020.

9. A 10-year time lag for each world region was applied according to predicted emission standards or emission factors $\left(\mathrm{E}_{\mathrm{H} 2}\right.$ ) for LDVs from Fulton and Eads (2004). For example, LDV $E_{\mathrm{H} 2}$ derived for 2010 are based on the emission standards or assumed emissions predicted for each region as of 2000. This was done to account for older vehicles still present within the fleet following the introduction of a new emission standard. This was done only for the years 2010 and 2020 (see assumption 11).

10. For large buses, medium-sized trucks, and mini-buses, emission factors were derived based on the assumed average emissions for each vehicle stock from Fulton and Eads (2004). In contrast to the LDVs (assumption 9), average emissions are provided for each time period rather than adopted emissions standards for these vehicle technologies. Thus, for these vehicle technologies, a time lag was not applied since an average emission for each vehicle technology and time period was provided. This was done only for the years 2010 and 2020 (see assumption 11).

11. Beyond 2020 (i.e. for 2050 and 2100) similar vehicle technologies were assumed to have the same $E_{\mathrm{H} 2}$, irrespective of world region. For example, conventional gasoline LDVs were assumed to have the same $\mathrm{E}_{\mathrm{H} 2}$ in Europe as in China. 
12. The calculation of emission factors from vehicles measured on a chassis dynamometer can be found in Bond et al. (2010). The derivation of other $\mathrm{E}_{\mathrm{H} 2}$ can be found in Bond et al. (2011a).

13. $\mathrm{E}_{\mathrm{H} 2}$ from technologies other than conventional gasoline and two-wheeler vehicles were assumed to be constant over time.

14. $\mathrm{E}_{\mathrm{H} 2}$ from diesel vehicles were assumed to be constant with time based on the consistently oxidising operating point of diesel engines (Bond et al., 2010).

In addition to these assumptions made for the global upscaling of emissions from transportation, leakage rates of $\mathrm{H}_{2}$ to the atmosphere from production, distribution, storage, and non-transportation-based end-use systems (Section 4.4.3) were deduced based on assumptions and information from personal communication from industrial and commercial sources, along with estimations from the literature (Zittel and Altmann, 1996; Schlapbach and Züttel, 2001; Burns et al., 2002; Kammen and Lipman, 2003; Lovins, 2003; Schultz et al., 2003; Tromp et al., 2003; Warwick et al., 2004; de Wit and Faaig, 2007; Sherif et al., 2007 Balzer, personal communication, 2008; Natkin, personal communication, 2008). $\mathrm{H}_{2}$ emissions from other fossil fuel-based processes such as industrial and residential heating systems are not accounted for in this study. However, $\mathrm{H}_{2}$ emissions from such systems have been found to expel only marginal $\mathrm{H}_{2}$ to the atmosphere (M.K. Vollmer, personal communication, 2010), suggesting that $\mathrm{H}_{2}$ emissions from other industrial processes not related to intentional (e.g. the petroleum refining, $\mathrm{NH}_{3}$ production, and $\mathrm{CH}_{3} \mathrm{OH}$ production industries) $\mathrm{H}_{2}$ production may also be minor (compared to $\mathrm{CO}$ ), particularly as fossil fuel consumption begins to decline, cleanup technologies improve, and renewable primary energy resources gain in market share.

\subsection{Results and discussion}

\subsubsection{Hydrogen emissions in vehicle exhaust gas: a qualitative survey}

Hydrogen emissions from today's vehicles powered by ICEs are dependent on several factors, including:

- the presence/absence of a TWC;

- the engine state (engine speed and torque), which is defined by the vehicle state (e.g. speed, acceleration);

- the quality of lambda control;

- vehicle and fuel type; and

- engine and catalyst temperature at start up. 
Ambient conditions (e.g. temperature, humidity) are also factors contributing to $\mathrm{H}_{2}$ in vehicle exhaust. For example, cold-start emissions increase at lower ambient temperatures (Weilenmann et al., 2009). However, specific results involving variable ambient conditions are not included here.

For vehicles that operate under typically fuel-rich conditions, the presence or absence and the state (fresh or aged) of the TWC dictates, to a large extent, the timing and magnitude of $\mathrm{H}_{2}$ emissions in vehicle exhaust. An example illustrating the predictability of $\mathrm{H}_{2}$ concentrations in raw gasoline exhaust is presented in Figure 4.3. D'Alleva and Lovell (1936), in their early twentieth-century study of the relationship of exhaust gas composition to the air/fuel ratio, revealed $\mathrm{H}_{2}$ concentrations in raw exhaust that decreased in a slight non-linear fashion as the air/ fuel ratio increased. In a recent study involving pre- and post-catalytic converter measurements of gasoline exhaust at various engine operating points, a similar relationship was confirmed (Vollmer et al., 2010). The consistency in the results from both studies illustrates the predictability of the combustion principle and the dependence of $\mathrm{H}_{2}$ emissions on the air/fuel ratio under fuel-rich conditions when not subject to the complexities of a TWC.

The state at which the engine is operated (engine speed and torque) is an important factor contributing to $\mathrm{H}_{2}$ emissions in vehicle exhaust. This observation is depicted in Figure 4.4a for a gasoline Euro-4 automobile over the course of the Common
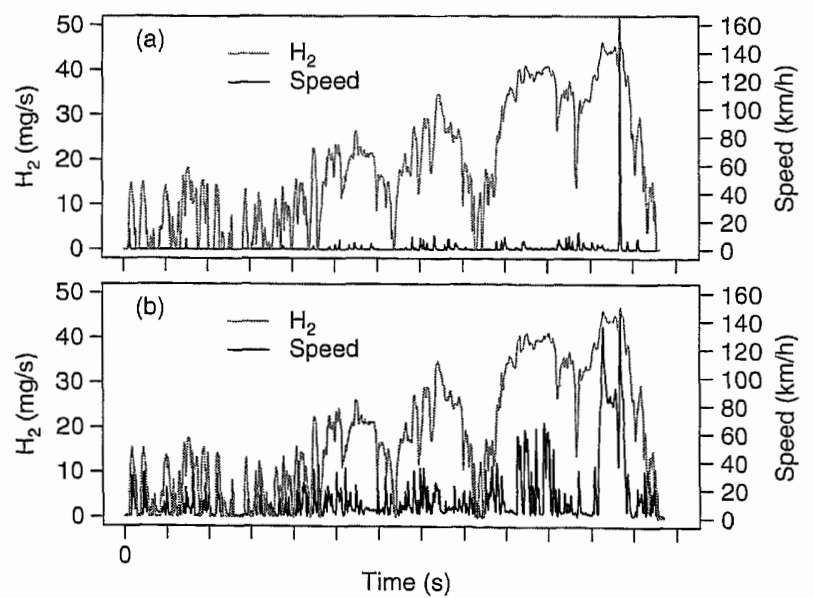

Figure $4.4 \mathrm{H}_{2}$ emissions from a gasoline Euro-4 automobile (a) and a gasoline Euro-3 motorcycle (b). The high emissions for the automobile at the end of the cycle are due to the engine control unit switching to a fuel-rich (low lambda) regime under high engine speed and load conditions. Emissions from the automobile are much lower throughout the cycle due to the more sophisticated lambda control system compared with the motorcycle, which displays consistently higher emissions under the same driving conditions, irrespective of the engine state. 
Artemis Driving Cycle (CADC). The greatest emissions occur under conditions of high engine speed and torque. These high rpm (revolutions per minute) and load situations occur at greater speeds and during periods of acceleration, or when a vehicle requires significant power to climb a hill, for example. Fuel-rich conditions also equate to more power. Thus, although high $\mathrm{H}_{2}$ emissions are typically most prominent as speeds approach the upper end of the speed range for a highway-based chassis dynamometer sub-cycle, high $\mathrm{H}_{2}$ emissions would also be observed if slope profiles were likewise incorporated into the driving cycles. In order to prevent the engine from overheating under such conditions, some ECUs are set to convert to a fuel-rich regime as the excess evaporated fuel cools the engine and TWC.

However, emissions from current ICEVs are not simply a result of the engine state, but also of the quality of lambda $(\lambda)$ control. $\mathrm{H}_{2}$ emissions are elevated in cycles with higher proportions of fuel-rich phases, and fuel-rich phases are more frequent with less sophisticated $\lambda$ control systems. This is evident in Figure 4.4a with emissions only markedly elevated as the automobile accelerates at already high vehicle speed. Hydrogen emissions from two-wheelers tend to be substantially greater than from gasoline-powered automobiles, largely due to the less developed ECUs for motorcycles, resulting in less precise $\lambda$ control and higher emissions, despite identical driving conditions. Figure $4.4 \mathrm{~b}$ illustrates this phenomenon for a Euro-3 motorcycle.

Vehicle and fuel type are further parameters that largely dictate the magnitude of $\mathrm{H}_{2}$ in ICEV emissions. Figure 4.5 depicts $\mathrm{H}_{2}$ emissions from a motorcycle (A), a natural gas automobile (B), a gasoline automobile (C), and a diesel automobile (D). Emissions are depicted as cumulative emissions in milligrams ( $\mathrm{mg}$ ) over the CADC driving cycle. The highest $\mathrm{H}_{2}$ emissions from vehicles tested in this study

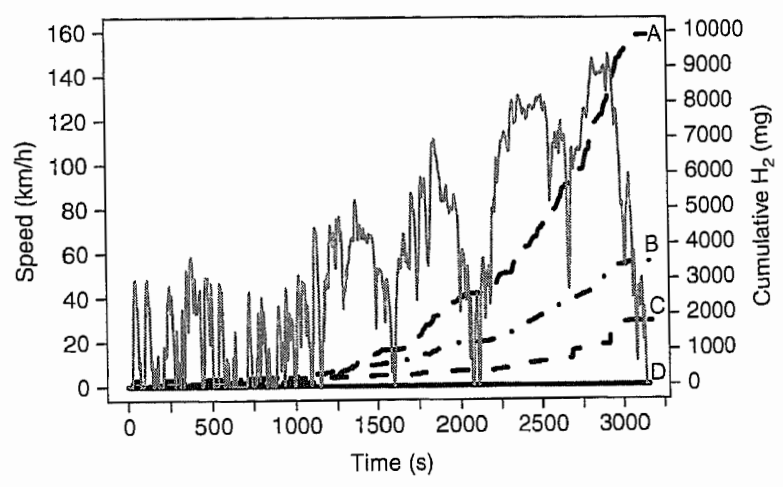

Figure 4.5 Cumulative $\mathrm{H}_{2}$ emissions for a motorcycle (A), natural gas automobile (B), gasoline automobile (C), and diesel automobile (D). Emissions (in $\mathrm{mg}$ ) are depicted by the variable black lines. The speed profile for the CADC driving cycle is depicted by the solid line. 


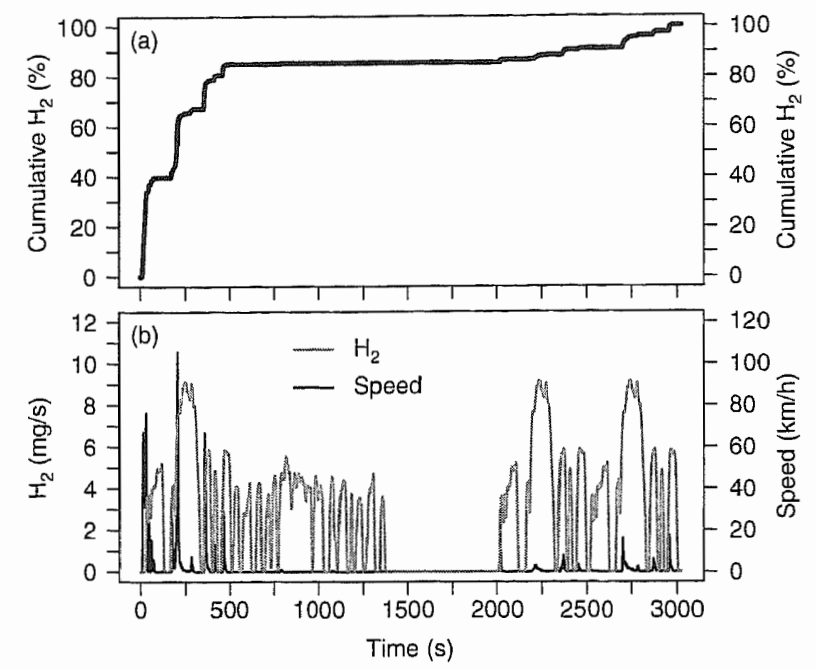

Figure 4.6 Importance of a cold start for a gasoline Euro-4 automobile. (a) Approximately $40 \%$ of total emissions are due to the cold start, with an additional $25 \%$ of the total occurring during the first major acceleration event. (b) $\mathrm{H}_{2}$ emissions (mg/s) and the speed profile of the United States Federal Test Procedure FTP-75 are depicted by the black and grey lines, respectively.

resulted from two-wheelers, followed by natural gas vehicles, gasoline automobiles, and diesel vehicles ${ }^{5} . \mathrm{H}_{2}$ emissions from gasoline-powered vehicles are much higher than those from diesel-powered vehicles, and in many instances $\mathrm{H}_{2}$ is not detectable at all over the course of a typical driving cycle conducted by a diesel vehicle. This is expected due to the constant oxidising combustion characteristic of diesel vehicles. $\mathrm{H}_{2}$ emissions from natural gas vehicles are generally higher than for gasoline-based vehicles because the hydrogen-carbon ratio in natural gas is approximately double that of gasoline. Furthermore, emissions from natural gas vehicles also have higher water vapour content, which facilitates a greater degree of water-gas shift activity.

The temperature of the engine and TWC are further important parameters dictating emissions of $\mathrm{H}_{2}$ from a vehicle. Figure 4.6 illustrates the importance of cold-start emissions from a gasoline-powered Euro-4 automobile. For a ride of $23.5 \mathrm{~km}$ in this example, approximately $40 \%$ of total $\mathrm{H}_{2}$ emissions occur at ignition of the cold engine, with an additional $25 \%$ of total emissions resulting from the first major acceleration event (Figure 4.6a). The rate of emissions $(\mathrm{mg} / \mathrm{s})$ and

\footnotetext{
5 The purpose of the cumulative emissions depicted in Figure 4.5 is to qualitatively illustrate how vehicle and fuel type may affect $\mathrm{H}_{2}$ emissions, and not to make any quantitative statements regarding the average of all vehicles powered by such fuel types (apart from the diesel vehicle, D). However, the total cumulative emissions from the vehicles depicted in Figure 4.5 do reflect the hierarchy of mean $\mathrm{H}_{2}$ emissions factors of the measured vehicles (Bond et al., 2010).
} 
the speed profile of the United States Federal Test Procedure FTP-75 are depicted by the black and grey lines in Figure 4.6b, respectively. Emissions are significantly higher during the cold start (Weilenmann et al., 2005). When prolonged, fuel-rich conditions do not dominate the cumulative emissions (e.g. during urban or rural driving conditions), cold-start emissions generally contribute the greatest cumulative $\mathrm{H}_{2}$ emissions. An initially cold catalyst needs to attain a minimum temperature before reaching an operationally high conversion rate. The light-off temperature is often used to describe the temperature at which the catalyst becomes more than $50 \%$ effective with respect to CO oxidation (Heywood, 1988). This temperature is above $200^{\circ} \mathrm{C}$ (Favez et al., 2009). In addition, most gasoline cars are run with a rich air/fuel ratio at start up because this guarantees the smooth running of the cold engine where gasoline condenses on the cold walls. The ECU usually then converts to $\lambda=1$ at the catalyst light-off temperature. Cold-start emissions generally affect all vehicle and fuel types measured in this study, although their relative magnitude in terms of total emissions is different for each vehicle, fuel type, and cycle driven. An advantage of natural gas vehicles over conventional gasoline-powered vehicles is the reduced cold-start and low temperature emissions (Thurnheer et al., 2009).

\subsubsection{Hydrogen emission factors and global scaling of transportation emissions}

In this section, $\mathrm{E}_{\mathrm{H} 2}$ from the vehicle technologies relevant to this study are used to upscale $\mathrm{H}_{2}$ emissions and project global emission scenarios from road-based transportation. The ongoing tightening of regulations has resulted in the systematic improvements of engines, TWCs, and engine controls to reduce the number and length of fuel-rich events and, hence, emissions of $\mathrm{CO}$ and hydrocarbons. In parallel, $\mathrm{H}_{2}$ emissions have also decreased in newer generations of cars. This is apparent in the $\mathrm{E}_{\mathrm{H} 2}$ found by Heeb et al. (2006) and Vollmer et al. (2007) - studies involving slightly older gasoline vehicle technologies - compared with the lower $\mathrm{E}_{\mathrm{H} 2}$ of gasoline Euro-4 automobiles (Bond et al., 2010). Table 4.1 provides an overview of all the $\mathrm{E}_{\mathrm{H} 2}$ for vehicles considered in this chapter.

The emission factors listed in Table 4.1 were applied in combination with vehicle kilometres driven by technology and world region (see Table 4.1 caption) in order to globally upscale $\mathrm{H}_{2}$ emissions from road-based transportation (Bond et al., 2011a). Table 4.2 lists results of the global projections (in Tg/year). Current conditions represent $\mathrm{H}_{2}$ emissions based on global kilometres travelled and vehicle fleet composition according to the baseline scenario (i.e. no effective climate policy implementation) since it was assumed that the efforts to mitigate climate change to date have had an inconsequential effect on a global scale. For 2020, 2050, and 2100 , results have been applied for both the baseline scenario and the $450 \mathrm{ppm}$ 
Table 4.2. Global projections of $\mathrm{H}_{2}$ emissions (Tg/year) from road-based transportation under both the baseline and the 450 ppm $\mathrm{CO}_{2}$ climate policy scenarios.

\begin{tabular}{|c|c|c|}
\hline Year & Baseline scenario & $450 \mathrm{ppm} \mathrm{CO}_{2}$ climate scenario \\
\hline 2010 & 4.51 & - \\
\hline 2020 & 2.33 & 2.33 \\
\hline 2050 & 1.08 & $1.05^{a}$ \\
\hline 2100 & 1.20 & $0.77^{a}$ \\
\hline
\end{tabular}

a Assuming no net $\mathrm{H}_{2}$ emissions from fuel cell vehicles.
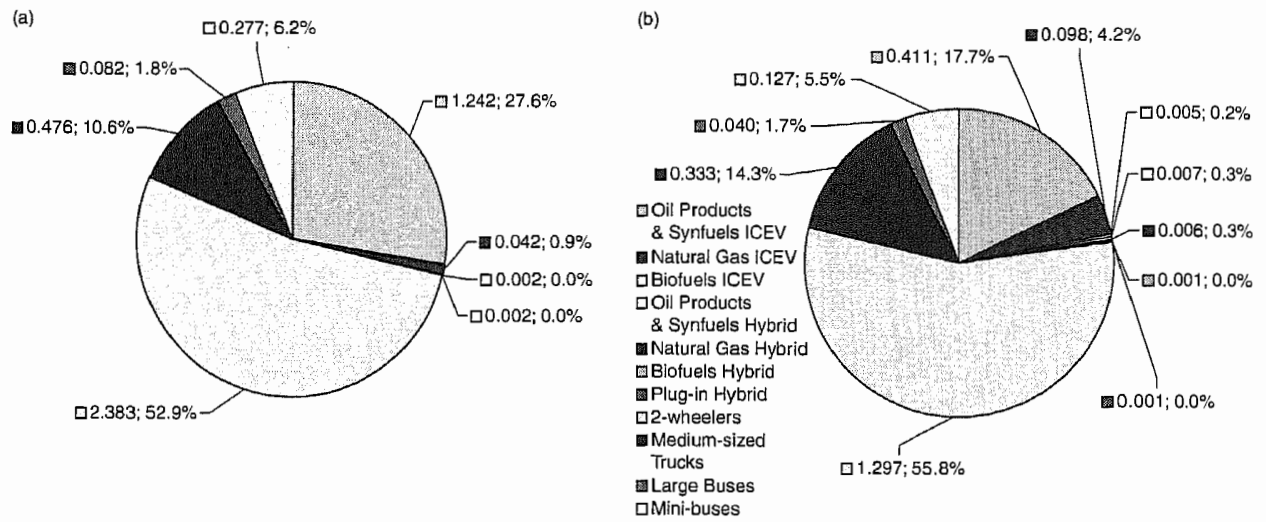

Figure $4.7 \mathrm{H}_{2}$ emissions from each vehicle technology in 2010 (a) and 2020 (b) separated by absolute emissions (in $\mathrm{Tg}$ ) and percentage of total emissions (see also colour plate 10).

$\mathrm{CO}_{2}$ climate policy scenario. For the breakdown of global LDV kilometres for the baseline and $450 \mathrm{ppm} \mathrm{CO}_{2}$ climate policy scenarios, see Chapter 6, Figures 6.8 and 6.9 , respectively.

Global $\mathrm{H}_{2}$ emissions from transportation are projected at $4.51 \mathrm{Tg}$ for 2010 . Emissions are dominated by two-wheelers ( $\sim 53 \%)$, along with conventional (predominantly gasoline) ICEVs ( 27.5\%), and the 'other' category, consisting of medium-sized trucks, large buses, and mini-buses $(\sim 18.5 \%)$, the emissions from which are also dominated by the gasoline-powered vehicles. Natural gas ICEVs account for $\sim 1 \%$ of total emissions (and $\sim 3 \%$ of LDV emissions), while biofuels and gasoline hybrid-electric vehicles (HEVs) each make up $<0.1 \%$. Figure 4.7 depicts the $\mathrm{H}_{2}$ emissions from each of the contributing vehicle technologies in 2010 (a) and 2020 under the $450 \mathrm{ppm} \mathrm{CO}_{2}$ climate policy scenario (b), respectively. Figure 4.8 separates the vehicle technologies further into emissions by world region for each technology. 
(a)

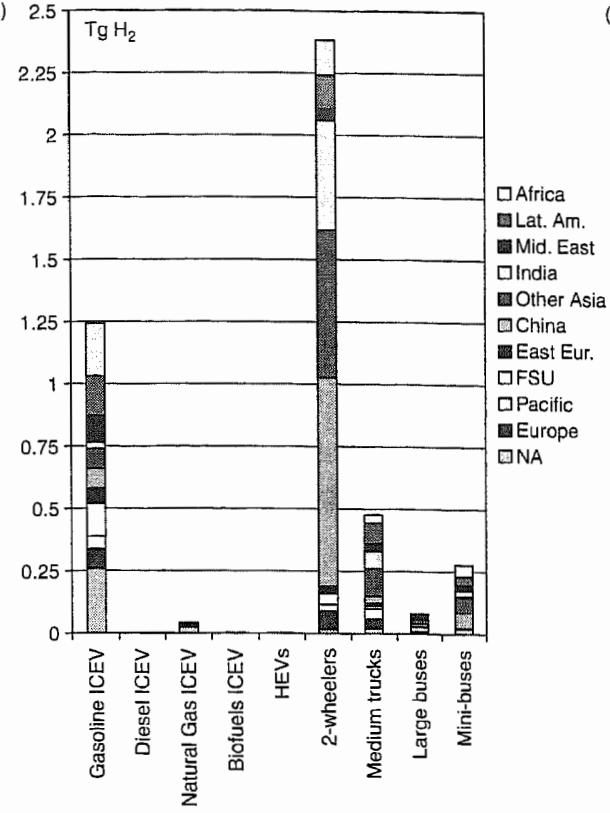

(b)

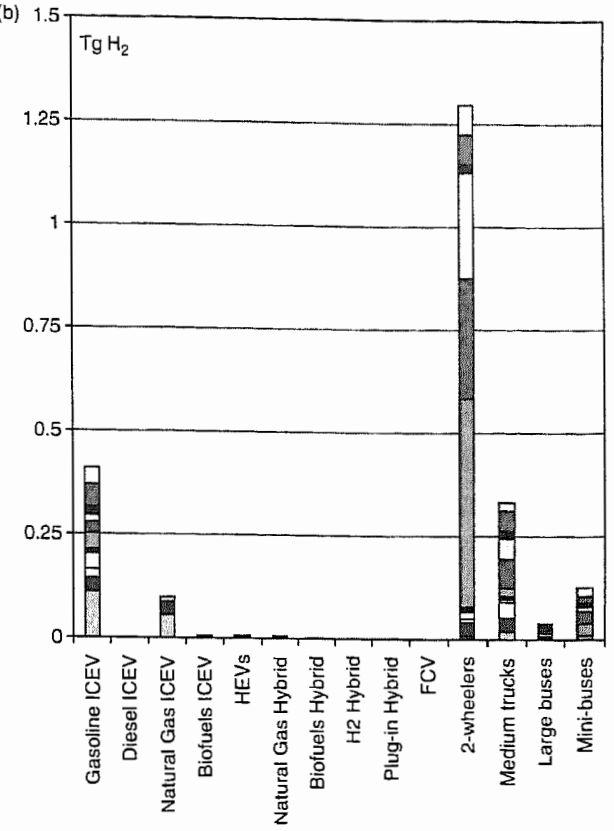

Figure $4.8 \mathrm{H}_{2}$ emissions from each vehicle technology in 2010 (a) and 2020 (b) separated by the absolute contribution (in $\mathrm{Tg}$ ) from each world region (note the difference in scales) (see also colour plate 11).

Global $\mathrm{H}_{2}$ emissions projections for 2020 result in $2.33 \mathrm{Tg}$ under both scenarios due to very similar vehicle fleet compositions. These projections are approximately half of that projected for 2010, primarily due to tightening emission standards and corresponding improvements in exhaust after-treatment systems, despite the greater number of global vehicle kilometres travelled (VKT). The rate of decrease from 2010-2020 ( 6.5\%/year) is broadly in line with that projected by Vollmer et al. (2007) for the period 2004-2015, based on the measured $\mathrm{H}_{2} / \mathrm{CO}$ ratio $(7.3 \% /$ year). In 2020, the same general picture is apparent with two-wheelers $(\sim 56 \%)$, conventional ICEVs $(\sim 18 \%)$, and the group of other vehicles $(\sim 21.5 \%)$ making up the vast majority of total $\mathrm{H}_{2}$ emissions. Natural gas ICEVs account for $\sim 4 \%$ of total $\mathrm{H}_{2}$ emissions from transportation (18.5\% of LDV emissions), while the group with biofuels vehicles, gasoline HEVs, natural gas hybrids, biofuel hybrids, and plug-in hybrids accounts for a combined $0.5 \%$ of the total.

In 2050 , emissions are expected to be the same within each vehicle technology class, irrespective of world region (see Table 4.1). FCVs account for $8.3 \%$ of the global LDV vehicle kilometres under the $450 \mathrm{ppm}$ climate policy; FCVs do not penetrate the global vehicle fleet at all under the baseline scenario. An $\mathrm{E}_{\mathrm{H} 2}$ of $\sim 43$ $\mathrm{mg} / \mathrm{km}$ has been reported for a cryogenic liquid $\mathrm{H}_{2}$ ICEV (Wallner et al., 2008), 
but to our knowledge, published $\mathrm{E}_{\mathrm{H} 2}$ data for FCVs do not exist. Here, we have selected two criteria for FCV emissions when assessing emissions from transportation in 2050 and 2100: (1) no net $\mathrm{H}_{2}$ emissions from FCVs; and (2) $\mathrm{FCV} \mathrm{E}_{\mathrm{H} 2}$ that would maintain overall $\mathrm{H}_{2}$ emissions from transportation within the realm of current and near-term estimates. The reason for the selection of these FCV $\mathrm{E}_{\mathrm{H} 2}$ is: (1) to illustrate overall road-based transport emissions based on optimal fuel cell efficiency and complete recycling of purged $\mathrm{H}_{2}$, for example, through the development of catalytic burners in the fuel cell exhaust systems, and (2) to illustrate upperend boundaries using current emissions as an acceptable guide, as it is currently unknown to what extent an increasing anthropogenic $\mathrm{H}_{2}$ source would be balanced by increasing removal of atmospheric $\mathrm{H}_{2}$ through soil oxidation, for example. As a third independent criterion in 2100, we have selected a small set of FCV $\mathrm{E}_{\mathrm{H} 2}$ $(265 \mathrm{mg} / \mathrm{km}, 200 \mathrm{mg} / \mathrm{km}$, and $70 \mathrm{mg} / \mathrm{km}$ ) to provide a quantitative picture of overall transport-based $\mathrm{H}_{2}$ emissions based on various mean FCV $\mathrm{E}_{\mathrm{H} 2}$. These FCV $\mathrm{E}_{\mathrm{H} 2}$ have not been entirely arbitrarily chosen; the selected highest $\mathrm{E}_{\mathrm{H} 2}(265 \mathrm{mg} / \mathrm{km})$ is based on what we consider to be a high-end $\mathrm{FCV} \mathrm{E}_{\mathrm{H} 2}$, which is in accordance with our knowledge of emissions from prototype FCVs. A reduction in emissions of $50 \%$ for production FCVs by 2020 is conceivable (C. Bach, personal communication, 2010). For an overview of emissions scenarios where set low- and high-end $\mathrm{FCV} \mathrm{E}_{\mathrm{H} 2}$ have been selected, see Bond et al. (2011a).

Discounting the $\mathrm{H}_{2}$ contribution from FCVs for now, baseline conditions result in $1.08 \mathrm{Tg} \mathrm{H}_{2}$ from transportation in 2050 , while $450 \mathrm{ppm} \mathrm{CO}_{2}$ policy conditions

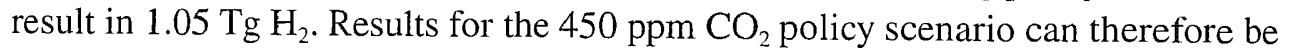
interpreted as road-based emissions if FCVs were to achieve no net $\mathrm{H}_{2}$ emissions. Reasons for the perpetual decrease in $\mathrm{H}_{2}$ emissions are, again, emissions regulations stringency and improvements in exhaust after-treatment systems, particularly now in the world's less developed regions, where a previous vehicle technology time lag existed, and where the highest emissions are typically found in the near term. By 2050, the shift from conventional gasoline vehicles to emerging technologies such as biofuels and hybrid vehicles is marked, and this development plays an important role in the decrease in global $\mathrm{H}_{2}$ emissions. The introduction of the Euro-4 and Euro-5 emission standards for two-wheelers in the coming decade should reduce two-wheeler emissions significantly, conceivably to levels of current technology automobiles (ACEM, 2010). This is a primary reason why $\mathrm{H}_{2}$ emissions are expected to decrease considerably throughout the twenty-first century, despite perpetually increasing kilometres travelled globally by two-wheelers.

Although FCVs contribute less than $10 \%$ of global vehicle kilometres in 2050, it is illustrative to consider how emissions from FCVs may relate to current and nearterm emissions scenarios. Based on global vehicle kilometres under the $450 \mathrm{ppm}$ $\mathrm{CO}_{2}$ climate policy scenario and vehicle $\mathrm{E}_{\mathrm{H} 2}$ projected for 2050 , we estimate that a 
range of $\mathrm{E}_{\mathrm{H} 2}$ for FCVs of $600-1625 \mathrm{mg} / \mathrm{km}$ would result in similar global $\mathrm{H}_{2}$ emissions from transportation as conditions from 2010-2020 (2.33-4.51 Tg). In other words, barring a major breakdown in the development of fuel cell efficiency during the first half of this century, emissions from transportation in 2050 are expected to remain well below those currently observed. To put this last statement into a quantitative perspective, a FCV $\mathrm{E}_{\mathrm{H}_{2}}$ of $\sim 16 \mathrm{mg} / \mathrm{km}$ under the $450 \mathrm{ppm} \mathrm{CO}_{2}$ climate policy scenario in 2050 would result in similar levels of $\mathrm{H}_{2}$ from transportation that is estimated under the baseline scenario $(\sim 1.08 \mathrm{Tg})$.

By 2100, FCVs are expected to make up an estimated $80 \%$ of global LDV VKT under the $450 \mathrm{ppm} \mathrm{CO}_{2}$ climate policy scenario (see Chapter 6); again, FCVs are not expected to penetrate the global vehicle fleet under the baseline scenario. $\mathrm{H}_{2}$ emissions from transportation under the baseline scenario are estimated at $\sim 1.20$ $\mathrm{Tg}$. Assuming no net $\mathrm{H}_{2}$ emissions from FCVs under the $450 \mathrm{ppm}$ target scenario, road-based $\mathrm{H}_{2}$ emissions are estimated at $\sim 0.77 \mathrm{Tg}$. Two-wheelers still represent approximately $33 \%$ of total road-based $\mathrm{H}_{2}$ emissions in 2100 under baseline conditions, but make up only $\sim 16 \%$ of two-wheeler emissions from 2010 in absolute terms. Under the $450 \mathrm{ppm} \mathrm{CO}_{2}$ policy scenario, an $\mathrm{E}_{\mathrm{H} 2}$ range of $55-135 \mathrm{mg} / \mathrm{km}$ from FCVs is estimated to result in $\mathrm{H}_{2}$ emissions from transportation remaining within the realm of current and near-term (2020) global $\mathrm{H}_{2}$ emissions from transportation $(2.33-4.51 \mathrm{Tg})$. It is clear that the $\mathrm{E}_{\mathrm{H} 2}$ for $\mathrm{FCVs}$ would have to be significantly lower in 2100 than in 2050 due to the sheer number of vehicle kilometres driven by FCVs. In 2050 (under the $450 \mathrm{ppm}$ policy scenario), FCVs will travel approximately 2.1 trillion kilometres globally, while in 2100 , FCVs will travel approximately 27.5 trillion kilometres.

As a comparison for global $\mathrm{H}_{2}$ emissions from transportation in 2100 , hypothetical $\mathrm{E}_{\mathrm{H} 2}$ for FCVs of 265,200 , and $70 \mathrm{mg} / \mathrm{km}$ would result in total $\mathrm{H}_{2}$ emissions from road-based transportation of approximately $8.1,6.3$, and $2.7 \mathrm{Tg}$ - values 1.8 , 1.4 , and 0.6 times 2010 levels, respectively. Figure 4.9 portrays this comparison graphically. The first column represents 2010 baseline conditions. The four additional columns (2100a, b, c, and d) represent 2100 projections for $\mathrm{H}_{2}$ emissions from road-based transportation based on the $450 \mathrm{ppm} \mathrm{CO}_{2}$ policy scenario for various FCV $E_{\mathrm{H} 2}$. The first two columns (2100a and b) represent total road-based emissions considering FCV $E_{\mathrm{H} 2}$ of 270 and $200 \mathrm{mg} / \mathrm{km}$, respectively. The third column $(2100 \mathrm{c})$ represents total transportation-based emissions with a mean FCV $\mathrm{E}_{\mathrm{H} 2}$ of $135 \mathrm{mg} / \mathrm{km}$. The comparison with emissions in 2010 shows that this FCV $\mathrm{E}_{\mathrm{H} 2}$ in 2100 will maintain total transportation-based $\mathrm{H}_{2}$ emissions similar to current levels, despite increasing global kilometres travelled throughout the twenty-first century. The final column (2100d) represents total transportation-based emissions according to an $F C V E_{\mathrm{H} 2}$ of $70 \mathrm{mg} / \mathrm{km}$. In this case, total emissions are considerably lower than 2010 emissions. In all cases, it is apparent that $\mathrm{H}_{2}$ emissions from 


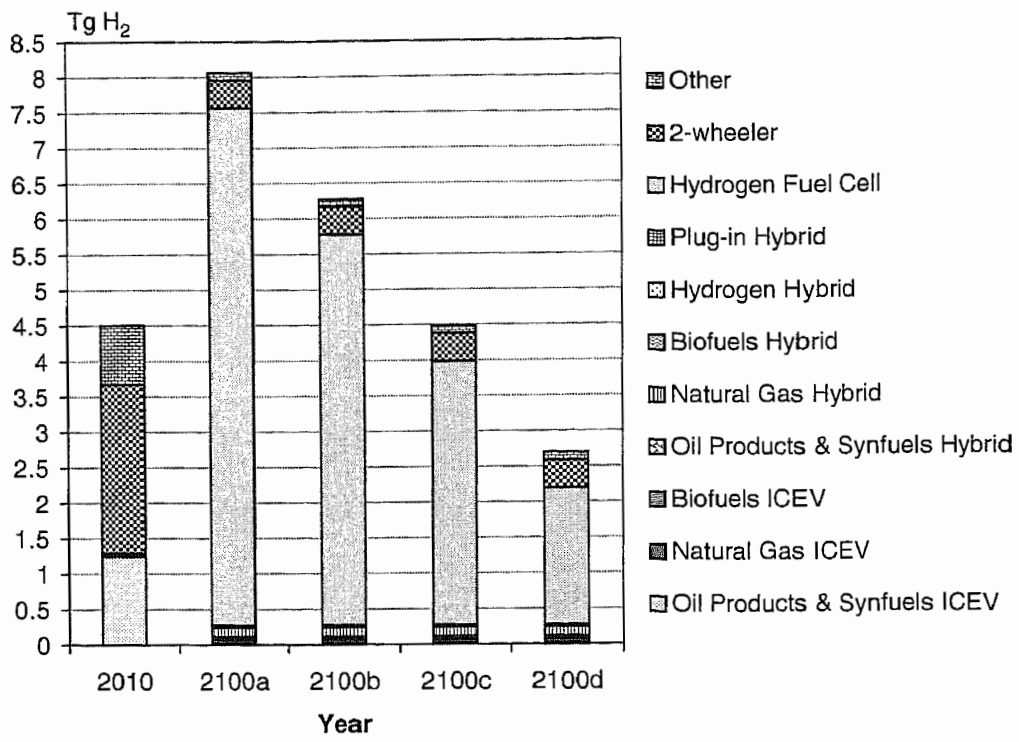

Figure $4.9 \mathrm{H}_{2}$ emissions in 2010 and 2100 separated by the absolute contribution from each vehicle technology (in $\mathrm{Tg}$ ) and illustrating scenarios based on variable $\mathrm{H}_{2}$ emission factors from fuel cell vehicles. The first two columns for 2100 ( $\mathrm{a}$ and $\mathrm{b}$ ) represent total road-based transportation $\mathrm{H}_{2}$ emissions based on an FCV $\mathrm{E}_{\mathrm{H} 2}$ of 265 and $200 \mathrm{mg} / \mathrm{km}$, respectively. Column $2100 \mathrm{c}$ represents total $\mathrm{H}_{2}$ emissions based on an FCV E $\mathrm{H}_{\mathrm{H} 2}$ of $135 \mathrm{mg} / \mathrm{km}$. With this FCV $\mathrm{E}_{\mathrm{H} 2}$ in 2100 , total road-based $\mathrm{H}_{2}$ emissions would be similar to total emissions in 2010. Column $2100 \mathrm{~d}$ represents total $\mathrm{H}_{2}$ emissions based on an $\mathrm{FCV} \mathrm{E}_{\mathrm{H} 2}$ of $70 \mathrm{mg} / \mathrm{km}$.

FCVs in 2100 make up a considerable fraction of total emissions because FCVs

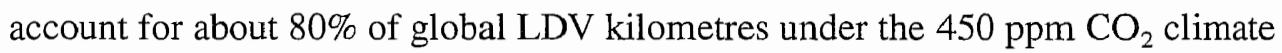
policy scenario.

In summary, $\mathrm{H}_{2}$ emissions from road-based transportation in 2010 and 2020 are dominated primarily by two-wheelers, gasoline-powered ICE LDVs, and a group of 'other' gasoline-powered vehicles consisting of medium-sized trucks, large buses, and mini-buses. The primary reason for the drastic decrease in emissions between 2010 and 2050 is the cleanup of emissions from two-wheelers, and to a lesser extent, those from gasoline-powered ICEVs and 'other' category of vehicles. Thus, transport-based $\mathrm{H}_{2}$ emissions in 2050 are expected to be significantly lower than in both 2010 and 2020. As an example, the $\mathrm{E}_{\mathrm{H} 2}$ of $265 \mathrm{mg} / \mathrm{km}$ used as a worst case scenario in 2100 would result in total $\mathrm{H}_{2}$ emissions from transportation of $1.6 \mathrm{Tg}$ in 2050, approximately one-third of 2010 transport-based emissions estimates. In $2100, \mathrm{FCV}$ s will have far more influence on transport-based $\mathrm{H}_{2}$ emissions than in 2050 due to the 13-fold increase in global FCV kilometres. Thus, smaller ranges of $\mathrm{FCV} \mathrm{E}_{\mathrm{H} 2}$ will have greater effects on total emissions. 
It has been demonstrated that fuel cells have a variable purge requirement in order to prevent the accumulation of inert gases, water, and impurities such as $\mathrm{CO}$ and $\mathrm{CO}_{2}$ in the anode channels (Ahluwalia and Wang, 2008; Owejan et al., 2009a, b). Purging at regular intervals occurs in order to maintain efficiency and stable cell performance (Yu et al., 2009), and since $\mathrm{H}_{2}$ is delivered via the anode channel, $\mathrm{H}_{2}$ is simultaneously purged during these events. An important consideration might therefore be how much effort will be invested in optimising the trade-off between fuel cell efficiency and loss of $\mathrm{H}_{2}$ to the atmosphere due to the purge requirement of fuel cells. Such an optimum has been demonstrated by Ahluwalia and Wang (2007), which could well ensure that future $\mathrm{H}_{2}$ losses to the atmosphere from marketed FCVs are minimised. As noted by Owejan et al., 2009a, b), water management is one of the key engineering challenges facing the commercialisation of proton-exchange membrane fuel cells, suggesting that such areas are already being contemplated. Further, the development of catalytic burners within the fuel cell exhaust systems is another initiative that would both reduce emissions of $\mathrm{H}_{2}$ to the atmosphere and improve fuel economy for FCVs.

\subsubsection{Current and future hydrogen emissions from hydrogen production, distribution, storage, and non-transportation end-use systems}

An important category of anthropogenic $\mathrm{H}_{2}$ emissions is that of leakage or other fugitive emissions from production, distribution, storage, and non-transportationbased end-uses. This category includes all direct energy and industrial end-use sectors (Bond et al., 2011a), except transportation. In 2010, global production of $\mathrm{H}_{2}$ for all end-uses has been estimated at $47.0 \mathrm{Tg}$ from Bond et al. (2011a). Currently, $\mathrm{H}_{2}$ production for industrial end-uses vastly outweighs that for direct energy-based end-uses. In the United States, for example, $99 \%$ of $\mathrm{H}_{2}$ production is used in the chemical and petrochemical industries, primarily the petroleum-refining and $\mathrm{NH}_{3}$ fertiliser production industries (EIA, 2008b). Although $\mathrm{H}_{2}$ production in these areas is projected to increase in the coming decades, due largely to increasing gasoline and diesel consumption, the rate at which $\mathrm{H}_{2}$ production increases is expected to slow as global oil supply declines and more advanced alternative energy technologies continue to gain market share (see Chapter 6).

Peak oil production is likely to occur in the first half of the twenty-first century (Aleklett et al., 2010). However, global $\mathrm{H}_{2}$ production in the refining industry will likely continue to increase even after the peak in oil supply, due to the decreasing quality petroleum feedstocks (e.g. oil sands), coupled with stricter environmental regulations (S. Schlag, personal communication, 2010). Based on global $\mathrm{H}_{2}$ production in the petroleum refining industry of $18.6 \mathrm{Tg}$ in 2010 (Bond et al., 2011a), 
Table 4.3. $\mathrm{H}_{2}$ production scenarios for industrial-and energy-based end-uses for the years 2010,2020,2050, and 2100. Figures have been provided for both the baseline and $450 \mathrm{ppm} \mathrm{CO}_{2}$ climate policy scenarios. Units are in $\mathrm{Tg} / \mathrm{year}$.

\begin{tabular}{|c|c|c|c|c|}
\hline \multirow[b]{2}{*}{ Year } & \multicolumn{2}{|c|}{ Baseline scenario } & \multicolumn{2}{|c|}{$450 \mathrm{ppm} \mathrm{CO} \mathrm{C}_{2}$ climate policy scenario } \\
\hline & Industrial & Direct energy & Industrial & Direct energy \\
\hline 2010 & 47.0 & $<0.1$ & - & - \\
\hline 2020 & 69.4 & 0.1 & 69.9 & 3.1 \\
\hline 2050 & 137.5 & 0.8 & 132.3 & 92.6 \\
\hline 2100 & 263.5 & 5.1 & 254.9 & 1436.6 \\
\hline
\end{tabular}

we consider global oil supply figures from Gül (2008) as a guide for projections of global $\mathrm{H}_{2}$ production in this industry throughout the twenty-first century. In parallel, we apply a continuous $1 \%$ annual growth rate in $\mathrm{H}_{2}$ production in the refining industry to account for the growing requirements of $\mathrm{H}_{2}$ per unit of refinery throughput. This results in $\mathrm{H}_{2}$ production of 34.1 and $46.0 \mathrm{Tg}$ under the baseline scenario for 2050 and 2100, respectively, and 28.9 and $37.3 \mathrm{Tg}$ under the $450 \mathrm{ppm}$ $\mathrm{CO}_{2}$ climate policy scenario in 2050 and 2100 , respectively.

For the other industrial end-uses (primarily $\mathrm{NH}_{3}$ and $\mathrm{CH}_{3} \mathrm{OH}$ production), we consider global economic growth rates as a guide for $\mathrm{H}_{2}$ demand in these industries. These growth rates are based on the B2 scenario of the Intergovernmental Panel on Climate Change's (IPCC) Special Report on Emissions Scenarios (SRES; IPCC, 2000), which is the same report from which long-term economic growth in Chapter 6 is derived (Gül, 2008). For the period 2020-2050, we apply an annual growth rate of $2.8 \%$, which is the same average growth rate projected for the period 1990-2050. For 2050-2100, we apply an annual growth rate of $1.5 \%$, which is considered an average value for the global economic growth projected for the period 1990-2100. This results in $\mathrm{H}_{2}$ production from the other significant industrial enduses (i.e. industrial end-uses other than petroleum refining) of 103.4 and $217.6 \mathrm{Tg}$ in 2050 and 2100, respectively. We do not assume production capacity for these end-uses to differ between climate policies.

For overall $\mathrm{H}_{2}$ production for all industrial end-uses, we first adopt the global $\mathrm{H}_{2}$ production and consumption projection of $69.4 \mathrm{Tg}$ (baseline) and $69.9 \mathrm{Tg}$ (450 ppm) for 2020 from Bond et al. (2011a). Based on the above projections for total industrial $\mathrm{H}_{2}$ production (i.e. petroleum refining and other industrial enduses), total $\mathrm{H}_{2}$ production for industrial end-uses is projected at 137.5 and $263.5 \mathrm{Tg}$ under the baseline scenario in 2050 and 2100 , respectively, while production is projected at 132.3 and $254.9 \mathrm{Tg}$ under the $450 \mathrm{ppm} \mathrm{CO}_{2}$ climate policy scenario in 2050 and 2100 , respectively (see Table 4.3 ). 
$\mathrm{H}_{2}$ production for direct energy-based end-uses (e.g. transportation, commercial and residential heat and power) has been projected with the GMM to 2100 (see Chapter 6); production is expected to increase considerably throughout the twenty-first century - an annual growth rate of 14.5\% from 2010-2100 under the $450 \mathrm{ppm} \mathrm{CO}_{2}$ climate policy (considering baseline production of $\mathrm{H}_{2}$ for direct energy services in 2010). Table 4.3 provides results of upscaled industrial and direct energy-based $\mathrm{H}_{2}$ production. Baseline and $450 \mathrm{ppm} \mathrm{CO}_{2}$ climate scenario projections are included for 2010, 2020, 2050, and 2100. Although industrial $\mathrm{H}_{2}$ production will still be greater in 2050 , direct energy-based $\mathrm{H}_{2}$ production would be more than five times higher than industrial $\mathrm{H}_{2}$ production in 2100 under the $450 \mathrm{ppm} \mathrm{CO}_{2}$ climate policy. Indeed, climate policies influence $\mathrm{H}_{2}$ production for direct energy services throughout the twenty-first century, and the more stringent the policy with respect to atmospheric $\mathrm{CO}_{2}$ concentrations, the more $\mathrm{H}_{2}$ is produced (see Chapter 6).

From Table 4.3, it is apparent that direct energy-based $\mathrm{H}_{2}$ production remains only a small fraction of total $\mathrm{H}_{2}$ production through to 2100 under the baseline scenario. Under the $450 \mathrm{ppm} \mathrm{CO}_{2}$ climate policy scenario, direct energy-based $\mathrm{H}_{2}$ production in 2020 also makes up only a small fraction of total $\mathrm{H}_{2}$ production $(\sim 4 \%)$. However by 2050 , the fraction of $\mathrm{H}_{2}$ produced for direct energy-based applications increases considerably to $41 \%$ of the total, while in 2100 , this figure reaches $85 \%$ of total $\mathrm{H}_{2}$ production.

Table 4.4 outlines the total global production capacity of $\mathrm{H}_{2}$ in 2010, 2020, 2050, and 2100 , along with a range of loss rates of $\mathrm{H}_{2}$ to the atmosphere from production, delivery, storage, and end-use systems.

If we consider a current loss rate range of $1-4 \%$ over the entire production, distribution, storage, and end-use chain (with $4 \%$ considered to be an upper-end figure), between 0.5 and $1.9 \mathrm{Tg} \mathrm{H}_{2}$ will be emitted to the atmosphere in 2010 under the baseline scenario. However, Zittel and Altmann (1996) and Schultz et al. (2003) have reported that losses of gaseous $\mathrm{H}_{2}$ from the existing $\mathrm{H}_{2}$ distribution grid in Germany are in the order of $0.1 \%$, suggesting that future systems should attain lower loss rates. This argument is driven primarily by financial, safety, and environmental concerns. For example, Air Liquide Deutschland GmbH is responsible for the largest hydrogen pipeline network in Germany. According to one of their engineers, the goal for $\mathrm{H}_{2}$ production, delivery, and storage is to achieve zero losses. In reality, however, a $0.1 \%$ leakage rate to the atmosphere is more realistic. A rate of $1 \%$ would result in massive annual monetary losses (F. Balzer, personal communication, 2008), an incentive for large industrial gas suppliers to minimise leakage of $\mathrm{H}_{2}$ to the atmosphere. By 2050 , under the $450 \mathrm{ppm} \mathrm{CO}_{2}$ climate policy, as the fraction of global $\mathrm{H}_{2}$ production for direct energy services begins to gain a foothold, a loss rate range of $0.1-2 \%$ is assumed to be representative over the entire 
Table 4.4. Overall global anthropogenic $\mathrm{H}_{2}$ emissions to the atmosphere from transportation and $\mathrm{H}_{2}$ production, delivery, storage, and other end-use systems. Global projections of $\mathrm{H}_{2}$ losses (Tg) under a range of loss rates (\%) have also been included. Total production and losses comprise $H_{2}$ production for both industrial-and energy-based end-uses. See Table 4.3 for the breakdown of total production between industrial-and energy-based end-uses. Projections are separated according to the baseline scenario and the 450 ppm $\mathrm{CO}_{2}$ climate policy scenario for the years 2010, 2020, 2050, and 2100. The first column of the overall anthropogenic emissions for 2050 and 2100 under the $450 \mathrm{ppm} \mathrm{CO}$ climate policy scenario represent overall emissions, should no net emissions from FCVs result; the second column when a fuel cell vehicle (FCV) $E_{H 2}$ would lead to total emissions from transportation similar to $2010\left(\sim 4.5 \mathrm{Tg}\right.$ ). These FCV $E_{H 2}$ correspond to $\sim 1625 \mathrm{mg} / \mathrm{km}$ in 2050 and $\sim 135 \mathrm{mg} / \mathrm{km}$ in 2100 .

\begin{tabular}{|c|c|c|c|c|c|c|c|c|c|c|c|}
\hline \multirow[b]{2}{*}{ Year } & \multicolumn{5}{|c|}{ Baseline scenario } & \multicolumn{6}{|c|}{$450 \mathrm{ppm} \mathrm{CO}_{2}$ climate policy scenario } \\
\hline & $\begin{array}{l}\text { Production } \\
\text { capacity } \\
(\mathrm{Tg})\end{array}$ & $\begin{array}{l}\text { Loss } \\
\text { rate } \\
(\%)\end{array}$ & $\begin{array}{l}\text { Total } \\
\text { loss } \\
\text { (Tg) }\end{array}$ & $\begin{array}{l}\text { Emissions } \\
\text { from } \\
\text { transport } \\
(\mathrm{Tg})\end{array}$ & $\begin{array}{l}\text { Overall } \\
\text { anthropogenic } \\
\text { emissions } \\
\text { (Tg) }\end{array}$ & $\begin{array}{l}\text { Production } \\
\text { capacity } \\
(\mathrm{Tg})\end{array}$ & $\begin{array}{l}\text { Loss } \\
\text { rate } \\
(\%)\end{array}$ & $\begin{array}{l}\text { Total } \\
\text { loss } \\
(\mathrm{Tg})\end{array}$ & $\begin{array}{l}\text { Emissions } \\
\text { from } \\
\text { transport } \\
(\mathrm{Tg})\end{array}$ & $\begin{array}{l}\text { Overal } \\
\text { anthro } \\
\text { emissi } \\
\text { (Tg) }\end{array}$ & genic \\
\hline \multirow[t]{4}{*}{2010} & 47.0 & 1.00 & 0.47 & 4.51 & 4.98 & - & - & - & - & - & \\
\hline & & 2.00 & 0.94 & & 5.45 & & - & - & & - & \\
\hline & & 3.00 & 1.41 & & 5.92 & & - & - & & - & \\
\hline & & 4.00 & 1.88 & & 6.39 & & - & - & & - & \\
\hline \multirow[t]{4}{*}{2020} & 69.5 & 0.50 & 0.35 & 2.33 & 2.68 & 73.0 & 0.50 & 0.37 & 2.33 & 2.70 & \\
\hline & & 1.00 & 0.70 & & 3.03 & & 1.00 & 0.73 & & 3.06 & \\
\hline & & 2.00 & 1.39 & & 3.72 & & 2.00 & 1.46 & & 3.79 & \\
\hline & & 4.00 & 2.78 & & 5.11 & & 4.00 & 2.92 & & 5.25 & \\
\hline \multirow[t]{4}{*}{2050} & 138.3 & 0.10 & 0.14 & 1.08 & 1.22 & 224.9 & 0.10 & 0.22 & 1.05 & 1.27 & 4.73 \\
\hline & & 0.20 & 0.28 & & 1.36 & & 0.20 & 0.45 & & 1.50 & 4.96 \\
\hline & & 0.50 & 0.69 & & 1.77 & & 0.50 & 1.12 & & 2.17 & 5.63 \\
\hline & & 2.00 & 2.77 & & 3.85 & & 2.00 & 4.50 & & 5.55 & 9.01 \\
\hline \multirow[t]{4}{*}{2100} & 268.6 & 0.01 & 0.03 & 1.20 & 1.23 & 1691.5 & 0.01 & 0.17 & 0.77 & 0.94 & 4.68 \\
\hline & & 0.05 & 0.13 & & 1.33 & & 0.05 & 0.85 & & 1.62 & 5.36 \\
\hline & & 0.10 & 0.27 & & 1.47 & & 0.10 & 1.69 & & 2.46 & 6.20 \\
\hline & & 0.50 & 1.34 & & 2.54 & & 0.50 & 8.46 & & 9.23 & 12.97 \\
\hline
\end{tabular}


production, distribution, storage, and end-use phases (excluding transportation) of the $\mathrm{H}_{2}$ life cycle. Under such conditions, losses of $\mathrm{H}_{2}$ to the atmosphere would be in the order of $0.2-4.5 \mathrm{Tg}$. Direct energy-based $\mathrm{H}_{2}$ applications would be responsible for $\sim 41 \%$ of these losses.

By 2100 , approximately $1400 \mathrm{Tg} \mathrm{H}_{2}$ will be produced for direct energy services, equivalent to $\sim 170 \mathrm{EJ}$ and $10 \%$ of primary energy consumption (total primary energy consumption of $\sim 1690 \mathrm{EJ}$ ) under the $450 \mathrm{ppm} \mathrm{CO}_{2}$ climate scenario. With $\mathrm{H}_{2}$ providing such a significant fraction of primary energy consumption, fully mature systems should be advanced enough to attain a maximum $0.5 \%$ loss rate of $\mathrm{H}_{2}$ due to safety, monetary, and ecological concerns. Leakage rates of $0.5 \%$ over the entire chain would result in emissions to the atmosphere in the order of approximately 8.5 $\mathrm{Tg} /$ year, with direct energy applications accounting for 7.2 Tg. Most hydrogen applications are fuelled by gaseous $\mathrm{H}_{2}$, however, from which losses to the atmosphere are significantly less than those from liquid $\mathrm{H}_{2}$ (Lovins, 2003). If we consider a loss rate of $0.1 \%$ over the entire production and end-use chain with the annual $\mathrm{H}_{2}$ production of $1690 \mathrm{Tg} /$ year for all end-uses, an annual leakage of $1.7 \mathrm{Tg} \mathrm{H}_{2}$ would result, with direct energy-based applications accounting for $1.4 \mathrm{Tg}$. In other words, by 2100 with a well-to-wheel $\mathrm{H}_{2}$ loss rate of $0.1 \%$, an economy reliant on $\mathrm{H}_{2}$ for approximately $10 \%$ of primary energy consumption would release a comparable amount of $\mathrm{H}_{2}$ into the atmosphere as estimations of today's anthropogenic, non-motor vehicle source of 0.5-2.0 Tg (Table 4.4). By 2100, lower loss rates are conceivable, and loss rates of $0.01 \%$ and $0.05 \%$ have been considered for illustrative purposes. Should such leakage rates be achieved by 2100 , well-to-wheel losses (excluding emissions from transportation) would be in the order of $0.17 \mathrm{Tg}$ and $0.85 \mathrm{Tg}$, respectively, at the lower end of current $\mathrm{H}_{2}$ emissions from the non-motor vehicle source.

It is apparent in Table 4.4 that, in the majority of cases, total losses remain within the realm of $\mathrm{H}_{2}$ production from the current non-motor vehicle source. Exceptions are the $4 \%$ loss rate in 2020 for both the baseline and $450 \mathrm{ppm} \mathrm{CO}_{2}$ climate policy scenarios, the $2 \%$ loss rate in 2050 for both scenarios, and the $0.5 \%$ loss rate for the 450 ppm $\mathrm{CO}_{2}$ climate scenario in 2100 . It should be noted, however, that these are all considered worst case loss rates for these time periods, and that industrial end-uses are also responsible for large fractions of the losses -95.7-99.9\% in 2020, $58.8-99.4 \%$ in 2050 , and $15.1 \%$ of losses under the $450 \mathrm{ppm} \mathrm{CO}_{2}$ climate policy in 2100 .

\subsubsection{Current and future overall anthropogenic hydrogen emissions from technological sources}

In this section, overall anthropogenic $\mathrm{H}_{2}$ emissions from technological sources (taken as the sum of road-based transportation emissions (Section 4.4.2) and 
emissions from hydrogen production, distribution, storage, and other non-transport, end-use systems (Section 4.4.3)) are combined and scaled-up to provide scenarios of overall direct anthropogenic $\mathrm{H}_{2}$ emissions to the atmosphere under 2010, 2020, 2050, and 2100 conditions. Table 4.4 outlines the results.

In 2010, based on a loss rate range of $1-4 \%$, overall baseline anthropogenic $\mathrm{H}_{2}$ emissions are estimated at 5.0-6.4 Tg. This range is at the lower end of overall fossil fuel-based anthropogenic $\mathrm{H}_{2}$ emissions from other studies (Novelli et al., 1999; Hauglustaine and Ehhalt, 2002; Sanderson et al., 2003; Price et al., 2007; Xiao et al., 2007). These lower-end estimations are possibly due in part to slight overestimations in other studies, as many of those estimates are based on scaling atmospheric $\mathrm{H}_{2}$ to the much more widely known $\mathrm{CO}$ inventories, due to the known positive correlation between $\mathrm{H}_{2}$ and $\mathrm{CO}$ in the exhaust gas of motorised vehicles (the most significant source of atmospheric $\mathrm{H}_{2}$ from fossil fuels). In support of this presumption, it has been shown that some fossil fuel combustion processes emit much smaller concentrations of $\mathrm{H}_{2}$ relative to $\mathrm{CO}$ compared with the exhaust gas of motor vehicles. For example, the flue gas of industrial and residential heating systems has been found to be much higher in $\mathrm{CO}$ than $\mathrm{H}_{2}$ (M.K. Vollmer, personal communication, 2010).

In 2020 , with a loss rate of $0.5-2 \%$, emissions would be lower than those estimated for current overall anthropogenic emissions. However, based on an assumed high-end loss rate of $4 \%$ under both the baseline and $450 \mathrm{ppm} \mathrm{CO}_{2}$ climate policy scenarios in 2020 , overall anthropogenic emissions would be within the range estimated for 2010.

The combined anthropogenic emissions column for both 2050 and 2100 has been split for the $450 \mathrm{ppm} \mathrm{CO}_{2}$ climate policy scenario. The first column represents combined emissions without accounting for $\mathrm{H}_{2}$ emissions from FCVs (i.e. no net $\mathrm{H}_{2}$ emissions from FCVs, see Section 4.4.2). The second column represents combined emissions based on FCVs contributing to overall emissions, such that emissions from transportation remain similar to the 2010 projection of $4.51 \mathrm{Tg}$. As detailed in Section 4.4.2, these $\mathrm{E}_{\mathrm{H} 2}$ for FCVs correspond to approximately 1625 $\mathrm{mg} / \mathrm{km}$ and $135 \mathrm{mg} / \mathrm{km}$ for 2050 and 2100 , respectively.

Considering only the $450 \mathrm{ppm} \mathrm{CO}_{2}$ climate policy scenario in 2050 - under the baseline scenario, virtually all $\mathrm{H}_{2}$ production is destined for industrial end-uses - loss rates of $0.1 \%$ and $0.2 \%$ would result in overall anthropogenic $\mathrm{H}_{2}$ emissions to the atmosphere of approximately 4.7 and $5.0 \mathrm{Tg}$, respectively, if emissions from FCVs are limited to $\sim 1625 \mathrm{mg} / \mathrm{km}$. Both of these estimations would be at the lower end of the range of current baseline anthropogenic $\mathrm{H}_{2}$ emissions estimations. A $0.5 \%$ and worst case $2 \%$ loss rate at such a production capacity (224.9 $\mathrm{Tg}$ ) would lead to anthropogenic $\mathrm{H}_{2}$ emissions of $\sim 5.6 \mathrm{Tg}$ and $\sim 9.0 \mathrm{Tg}$, respectively, should FCV emissions be held to a level that would lead to $\mathrm{H}_{2}$ emissions from transportation 
comparable to today. Under these conditions, overall emissions based on the $2 \%$ loss rate would exceed current overall anthropogenic $\mathrm{H}_{2}$ emissions estimations, whereas the $0.5 \%$ loss rate would result in similar overall emissions compared with today. Of course, $\mathrm{H}_{2}$ emissions from FCVs will almost certainly be substantially lower than $1625 \mathrm{mg} / \mathrm{km}$ for reasons detailed at the end of Section 4.4.2, suggesting that overall emissions from anthropogenic processes in 2050 will be largely dictated by leakage and losses and not transportation, and remain significantly lower than current estimates.

In 2100 under the $450 \mathrm{ppm} \mathrm{CO}_{2}$ policy scenario and based on a leakage and loss rate of $0.5 \%$ and an $\mathrm{FCV} \mathrm{E} \mathrm{H}_{2}$ of $135 \mathrm{mg} / \mathrm{km}$, overall anthropogenic $\mathrm{H}_{2}$ emissions would be roughly a factor of 2-2.5 higher than current emissions. However, based on a loss rate range of $0.01-0.1 \%$ and an $\mathrm{FCV} \mathrm{E}_{\mathrm{H} 2}$ of $135 \mathrm{mg} / \mathrm{km}$, overall anthropogenic $\mathrm{H}_{2}$ emissions to the atmosphere are projected to be within the range of 2010 estimates. In other words, under the $450 \mathrm{ppm} \mathrm{CO} 2$ climate policy scenario, and based on a well-to-wheel (excluding transportation) leakage range of $0.01-0.1 \%$ in 2100 , overall anthropogenic $\mathrm{H}_{2}$ emissions to the atmosphere should be, at worst, comparable with today's anthropogenic source of $\mathrm{H}_{2}$ from fossil fuels should $\mathrm{E}_{\mathrm{H} 2}$ for FCVs not exceed $\sim 135 \mathrm{mg} / \mathrm{km}$.

\subsection{Summary and conclusions}

Anthropogenic $\mathrm{H}_{2}$ emissions from fossil fuels originate primarily from the exhaust gas of motorised transportation and through losses and leakage from $\mathrm{H}_{2}$ production, storage, distribution, and end-use systems, with the former currently contributing the largest fraction to the overall source term of the global hydrogen budget. The majority of current $\mathrm{H}_{2}$ emissions from transportation result from the incomplete combustion of fossil fuels and depend on several factors, including the presence or absence of a TWC, engine speed and load, the quality of lambda control, vehicle and fuel type, engine and catalyst temperature at start up, and ambient conditions.

Current $\mathrm{H}_{2}$ emissions calculated from road-based transportation $(\sim 4.51 \mathrm{Tg})$ are at the lower end of the figures provided in previous literature $(\sim 5-20 \mathrm{Tg})$. Emissions from road-based transportation are expected to perpetually decrease throughout the twenty-first century as emission standards tighten, exhaust after-treatment systems develop and improve, and alternative vehicle technologies increase their market share in relation to conventional gasoline vehicles. Throughout the first half of the century, two-wheeler emissions are expected to dominate enissions from transportation, contributing $\sim 53 \%$ in 2010 and $\sim 56 \%$ in 2020 to total $\mathrm{H}_{2}$ emissions. Other, primarily gasoline-based, technologies account for the bulk of the remaining fractions. Non-conventional vehicles such as natural gas ICEVs, biofuels, and hybrid vehicles contribute to overall $\mathrm{H}_{2}$ emissions only very marginally in the first half 
of the century, and although their relative fraction and absolute number of global kilometres travelled increases, emissions from non-conventional vehicles remain small and never approach those of the most significant current technologies (i.e. four-wheeled gasoline-powered ICEVs and two-wheelers).

In the second half of the century, emissions from those technologies important throughout the first half of the century are expected to decrease considerably. In 2050 , as FCVs are estimated to account for $\sim 8 \%$ of global vehicle kilometres under a climate policy aimed at stabilising atmospheric $\mathrm{CO}_{2}$ concentrations at $450 \mathrm{ppm}$, a seemingly immense FCV $\mathrm{E}_{\mathrm{H} 2}$ of $\sim 1625 \mathrm{mg} / \mathrm{km}$ is estimated to maintain total $\mathrm{H}_{2}$ emissions from transportation at similar levels to those in 2010 . In 2100 , an $\mathrm{FCV} \mathrm{E}_{\mathrm{H} 2}$ of $\sim 135 \mathrm{mg} / \mathrm{km}$ is estimated to result in total emissions from transportation comparable to road-based transport emissions in 2010. This lower $\mathrm{E}_{\mathrm{H} 2}$ (more than an order of magnitude compared with 2050) is largely due to the 13-fold increase in global FCV kilometres driven between 2050 and 2100. For reference, FCV $E_{\mathrm{H} 2}$ of 265,200 , and $70 \mathrm{mg} / \mathrm{km}$ in 2100 are estimated to result in $\mathrm{H}_{2}$ emissions approximately $1.8,1.4$, and 0.6 times 2010 emissions from transportation, respectively. Should $\mathrm{H}_{2}$ emissions from FCVs remain below $135 \mathrm{mg} / \mathrm{km}$ throughout the century, total emissions from road-based transportation are projected to remain lower or comparable to today's estimated roadbased transport $\mathrm{H}_{2}$ emissions. Further research into the direct $\mathrm{H}_{2}$ emissions from FCVs would be beneficial, particularly into optimising the trade-off of fuel cell efficiency and purge losses of $\mathrm{H}_{2}$.

Losses and leakage of $\mathrm{H}_{2}$ to the atmosphere from production, storage, distribution, and end-use systems other than transportation should be driven throughout the coming century primarily by safety, ecological, and monetary concerns. Particularly as $\mathrm{H}_{2}$ production for direct energy-based end-uses begins to increase, efforts invested in controlling such losses should intensify. Through 2020, combined anthropogenic $\mathrm{H}_{2}$ emissions from transportation and well-to-wheel leakage based on a $0.5-4 \%$ leakage rate should remain within the realm of current overall emissions. Virtually all non-transport-based emissions would originate from industrial end-uses (primarily petroleum refining and ammonia production).

Based on a leakage rate range of $0.1-2 \%$ in 2050 , overall $\mathrm{H}_{2}$ emissions should remain either lower or within the range projected for 2010 conditions. This is even the case for all loss rates where an FCV $\mathrm{E}_{\mathrm{H} 2}$ of $1625 \mathrm{mg} / \mathrm{km}$ has been applied. An exception is the $2 \%$ loss rate under the $450 \mathrm{ppm} \mathrm{CO}_{2}$ climate policy scenario at this high $\mathrm{FCV} \mathrm{E}_{\mathrm{H} 2}$. In this case, overall anthropogenic emissions would be a factor of 1.4 to 1.8 higher than current overall emissions. However, considering the fact that average FCV emissions will almost certainly be substantially lower that $1625 \mathrm{mg} / \mathrm{km}$, overall emissions in 2050 should remain lower or within the realm of 2010 estimates. Irrespective of transport-based emissions, emissions from direct 
energy-based applications would only be responsible for $\sim 41 \%$ of non-transport emissions in 2050.

Considering a perhaps more representative leakage rate range of $0.01-0.1 \%$ from fully mature $\mathrm{H}_{2}$ systems and a likely more realistic FCV $E_{\mathrm{H}_{2}}$ of $135 \mathrm{mg} / \mathrm{km}$ in 2100 under the $450 \mathrm{ppm} \mathrm{CO}_{2}$ scenario, overall emissions would remain within the range of estimates for 2010 . With a leakage rate of $0.5 \%$ in 2100 , overall $\mathrm{H}_{2}$ emissions to the atmosphere would be a factor of 1.4 to 1.9 higher even if FCVs were to emit no $\mathrm{H}_{2}$. In 2100, under the predicted scenarios, direct energy-based end-uses would account for $\sim 85 \%$ of non-transport-related emissions. The keys here are minimising systems leakage and controlling emissions from FCVs.

In summary, climate objectives and vehicle fleet composition do not dictate to a large extent the overall emissions of $\mathrm{H}_{2}$ to the atmosphere in the first half of the twenty-first century. Rather, global levels of anthropogenic $\mathrm{H}_{2}$ in the atmosphere appear to be governed primarily by two-wheelers (at least until 2020), along with the variable loss rates from production, distribution, storage, and other nontransportation-based end-uses. Assuming an increase in FCVs after 2050, and particularly toward the end of the century, along with efforts invested in controlling leakage and other fugitive well-to-wheel emissions to the atmosphere, the mean $\mathrm{E}_{\mathrm{H} 2}$ for FCVs will largely influence overall anthropogenic $\mathrm{H}_{2}$ emissions. Negative effects of a future $\mathrm{H}_{2}$-intensive economy based on $\mathrm{H}_{2}$ emissions to the atmosphere alone are difficult to envisage if overall emissions remain at similar levels to those currently observed. In a large-scale context, $\mathrm{H}_{2}$ measurements at remote sites will contribute meaningfully to the monitoring of any fluctuations in the levels of atmospheric $\mathrm{H}_{2}$.

\subsection{Acknowledgements}

Thank you to M.K. Vollmer and M. Steinbacher from the Laboratory for Air Pollution/Environmental Technology at Empa for their assistance, along with interesting and useful comments regarding the atmospheric aspects of the chapter. Thank you to C. Bach and P. Soltic from the Laboratory for Internal Combustion Engines at Empa for helpful insights and discussions regarding the technical automotive aspects of the chapter. 